\title{
Radiolabeling Strategies of Nanobodies for Imaging Applications
}

\author{
Jim Küppers *, Stefan Kürpig, Ralph A. Bundschuh $\mathbb{D}^{\text {, }}$, Markus Essler and Susanne Lütje
}

Department of Nuclear Medicine, University Hospital Bonn, 53127 Bonn, Germany; stefan.kuerpig@ukbonn.de (S.K.); ralph.bundschuh@ukbonn.de (R.A.B.); markus.essler@ukbonn.de (M.E.); susanne.luetje@ukbonn.de (S.L.)

* Correspondence: patrick_jim.kueppers@ukbonn.de; Tel.: +49-228-28710338

check for

updates

Citation: Küppers, J.; Kürpig, S.; Bundschuh, R.A.; Essler, M.; Lütje, S. Radiolabeling Strategies of Nanobodies for Imaging Applications. Diagnostics 2021, 11, 1530. https:// doi.org/10.3390/diagnostics11091530

Academic Editor: Alexander Haug

Received: 1 July 2021

Accepted: 20 August 2021

Published: 25 August 2021

Publisher's Note: MDPI stays neutral with regard to jurisdictional claims in published maps and institutional affiliations.

\section{Copyright: (c) 2021 by the authors.} Licensee MDPI, Basel, Switzerland. This article is an open access article distributed under the terms and conditions of the Creative Commons Attribution (CC BY) license (https:/ / creativecommons.org/licenses/by/ $4.0 /)$.

\begin{abstract}
Nanobodies are small recombinant antigen-binding fragments derived from camelid heavychain only antibodies. Due to their compact structure, pharmacokinetics of nanobodies are favorable compared to full-size antibodies, allowing rapid accumulation to their targets after intravenous administration, while unbound molecules are quickly cleared from the circulation. In consequence, high signal-to-background ratios can be achieved, rendering radiolabeled nanobodies high-potential candidates for imaging applications in oncology, immunology and specific diseases, for instance in the cardiovascular system. In this review, a comprehensive overview of central aspects of nanobody functionalization and radiolabeling strategies is provided.
\end{abstract}

Keywords: nanobodies; labeling strategies; positron emission tomography; single photon emission computed tomography; radiometals; radiohalogens; molecular imaging

\section{Introduction}

Nanobodies $\left(\mathrm{V}_{\mathrm{H}} \mathrm{Hs}\right)$ represent recombinant single-domain variable fragments of heavy-chain-only antibodies (HCAbs), which themselves are obtained from species of the Camelidae family (Figure 1) [1]. With a molecular weight of 12-15 kDa, nanobodies are considered the smallest naturally occurring antigen-binding fragments [2]. They exhibit many beneficial features such as good water-solubility and (thermo)stability, high affinity and specificity as well as low immunogenicity, predestining them as excellent probes for molecular imaging applications $[1,3,4]$. A major advantage compared to conventional immunoglobulin G (IgG) antibodies is their rapid pharmacokinetics [5]. Due to their small size, nanobodies can reach their binding sites on the target tissues efficiently and quickly after injection, while the unbound fraction is rapidly cleared from the blood stream through renal elimination, potentially leading to high target-to-background ratios [6,7].

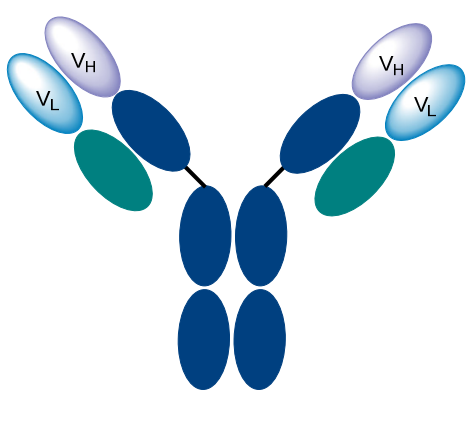

$\lg G$

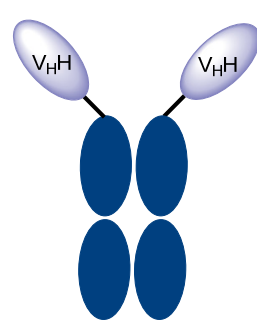

HCAb

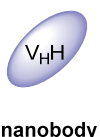

nanobody
Figure 1. Schematic representation of conventional immunoglobulin G's (IgGs), heavy chain-only antibodies (HCAbs) and nanobodies. $\mathrm{V}_{\mathrm{H}}$, variable heavy; $\mathrm{V}_{\mathrm{L}}$, variable light; $\mathrm{V}_{\mathrm{H}} \mathrm{H}, \mathrm{V}_{\mathrm{H}}$ of $\mathrm{HCAbs}$. 
Clinically, molecular imaging allows for noninvasive diagnosis of various ailments, disease-monitoring and therapy follow-up, as well as for patient selection and stratification at an early stage $[7,8]$. In order to depict (patho)physiological processes in vivo, a molecular tracer consisting of a targeting moiety and a detection label is appropriately administered into the patient's body [6]. While the former accomplishes the direction and specific accumulation of the probe, the latter enables the visualization of the tissue of interest [7]. For nuclear imaging purposes, a gamma-emitting isotope is used for single photon emission computed tomography (SPECT), while positron-emitting isotopes are used for positron emission tomography (PET). Typical SPECT isotopes comprise technetium-99 m and indium-111, while common PET isotopes include zirconium-89, copper-64, gallium-68 and fluorine-18. Since both techniques have their advantages in imaging, it is important to evaluate labeling for gamma emitters as well as positron emitters. Quantification in PET is easier than in SPECT imaging, where more individual calibration techniques are necessary [9]. SPECT, however, allows multi tracer imaging, as different energy windows can be scanned at the same time [10]. Clinical PET scanners also show a higher spatial resolution compared to clinical SPECT in most cases [11]; this is different in small animal imaging as spatial resolution of SPECT is not limited by the positron range, which is an intrinsic physical limit for the spatial resolution of PET.

It is important that the pharmacokinetic properties of the targeting vehicle are perfectly coordinated with the half-life of the radioisotope. Thus, due to their relatively slow pharmacokinetics, full-size IgG antibodies need to be combined with longer-lived radionuclides, such as zirconium-89 or indium-111 [12]. Upon administration, these radiolabeled antibodies require longer waiting periods for imaging, along with extended exposure to ionizing radiation for the patients. Such a longer accumulation time might affect the stability of the radiotracer and result in disintegration, leading to changes in the biodistribution profile and, via a misinterpretation of the scan, to a false diagnosis. Accordingly, they are less favorable for clinical applications. Conversely, nanobodies with more rapid pharmacokinetics attached to short-lived radionuclides, such as gallium-68 or fluorine-18, represent ideal imaging radiotracers [3].

In order to attain such tracers, the radiolabel may either be introduced into the single peptide chain of the nanobody as part of a prosthetic group, relating to radiohalogens (e.g., fluorine-18), or by means of complexation, concerning primarily radiometals (e.g., gallium-68) [12]. Direct radiohalogenation can require harsh reaction conditions, such as high temperatures and non-aqueous conditions, which are incompatible with nanobodies. Therefore, indirect labeling by using radiohalogen-containing prosthetic groups is most commonly performed for such antigen-binding proteins, although the procedure for synthesizing and purifying these radiolabeled groups requires extra time [3,12]. Contrary to this, radiometal labeling via chelation is usually conducted at the very end, immediately prior to application. Accordingly, the nanobody needs to be pre-modified with a chelating moiety in order to coordinate the radio-cation. Such a chelator can either be a synthesized organic molecule or of proteinogenic nature. Another way to introduce radiometals to nanobodies is via a heteroleptic complex, which is usually formed prior to attachment.

After intravenous administration, these nanobody-based radiotracers are rapidly cleared from the blood circulation through glomerular filtration due to their small size, followed by reabsorption in the proximal tubule, leading to a longer retention time in the renal cortex, which presents diagnostic as well as health concerns [7]. On the one hand, the associated intense renal signals impede imaging of molecular targets in close proximity to the kidneys. On the other hand, a long-term exposure with these tracers and their radio-catabolites implies a certain undesired nephrotoxicity. This refers especially to radio-catabolites derived from radiometal-labeled nanobodies, since radiohalogenated (fluorinated or iodinated) catabolites are usually hydrophobic and therefore rapidly excreted via the urine. In order to diminish the renal reabsorption of the tracers, a few techniques have been implemented. Since megalin/cubilin receptors in the proximal tubule play a decisive role for the reuptake, co-administration of the plasma expander gelofusin or posi- 
tively charged amino acids, such as arginine or lysine, can prevent the recovery through competition $[7,13]$. Apart from this, the tracer can be chemically modified, either by a cleavable linker (e.g., a renal brush border enzyme (BBE)-cleavable linker) inserted between the targeting moiety and the label so that an easier excretion of the radioactive metabolites into the urine is accomplished [14], or by an increase in the negative charge of the labeled entity, evoking a stronger electrostatic repulsion with the negatively charged proximal tubular cell surface [15].

Among the canonical amino acids within the nanobody, cysteine and lysine are most commonly addressed for radiolabeling [12]. While the thiol function of the former rapidly forms a thioether with a maleimide moiety, the primary $\varepsilon$-amino residue of the latter is easily acylated via activated esters or converted into stable thioureas through isothiocyanates, all of which enable the attachment of chelators or prosthetic groups to the nanobody (Figure 2). Whether their installation to its amino acid sequence is carried out randomly or site-specifically determines whether the radiotracer is obtained as a heterogenous or a homogenous product [7]. Unselective (random) conjugation as a classical strategy is convenient and has proven to be valuable; however, it can easily lead to hindered target recognition when the label is inserted within or in close proximity to the antigen binding site [16-18]. In order to better control the tracer conception, selective labeling at a specific attachment site is the favored approach. This review is aimed at providing an overview of the different synthetic strategies for radiolabeling nanobodies, which have been employed during the past decade and up to today.

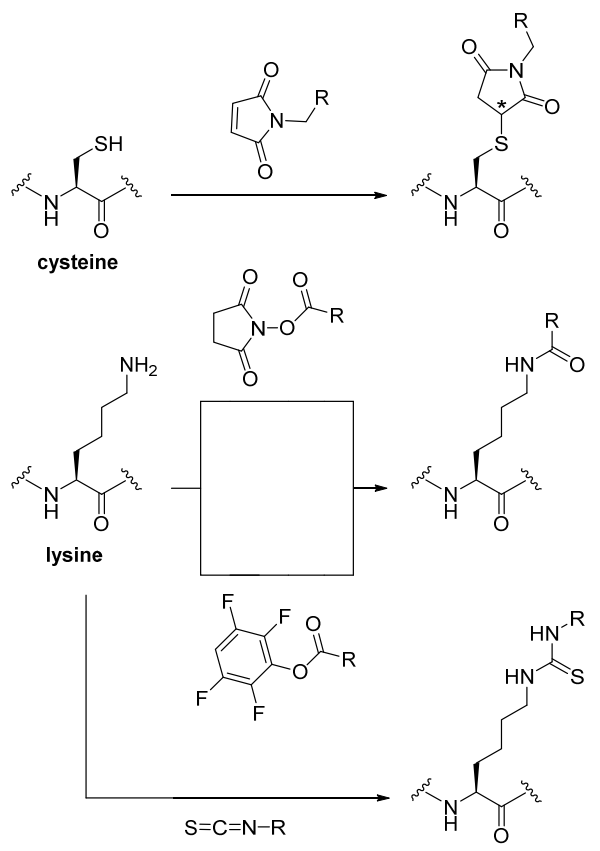

Figure 2. Common bioconjugation reactions for the attachment of radiolabels on cysteine and lysine residues within the nanobody [12]. Asterisk ${ }^{*}$ ) indicates a chiral center with an undefined ratio of the two stereoisomers.

\section{Radiolabeling Strategies of Nanobodies}

\subsection{Radiohalogens}

Radioiodines are well established in nuclear medicine [19], and among the clinically used isotopes, iodine-125 and iodine-131 can be applied for both diagnostic and therapeutic purposes [20]. Their gamma emission enables SPECT imaging, while additional radiation allows for disease treatment [19]. However, they both possess a relatively long half-life (59.6 days for iodine-125 [21]; 8.02 days for iodine-131 [22]), which is less desirable for imaging applications of nanobody-based radiotracers. A much better radiohalogen in this regard is the widely used PET imager fluorine-18 $\left(\mathrm{t}_{1 / 2}=110 \mathrm{~min}\right)$ [23], which is highly 
valued for its high positron yield on the one hand, leading to higher sensitivity, and its low positron energy on the other hand, optimizing resolution in imaging $[12,24]$.

\subsubsection{Direct Radiohalogenation}

While direct radiofluorination of nanobodies implies incompatible harsh reaction conditions, direct radioiodination using a well-established method with Iodogen $(1,3,4,6-$ tetrachloro- $3 \alpha, 6 \alpha$-diphenyl-glycoluril), a water-insoluble oxidant that is applied in order to minimize any protein damage through oxidation [25], has been performed by Pruszynski et al. [26,27]. Therein, the 5F7 nanobody, which specifically binds to the same epitope on the human epidermal growth factor receptor type 2 (HER2) as the known antibodies trastuzumab and pertuzumab, has been labeled with either iodine- 125 or iodine131, on constituent tyrosine residues of the nanobody's peptide chain, by electrophilic substitution. The phenolic hydroxyl group of tyrosine with its electron donating ability directs the positively charged iodine species obtained by iodide oxidation with Iodogen in the ortho position of the aromatic ring $[28,29]$, yielding a heterogenous mixture, wherein several tyrosines of the nanobody are either mono- or disubstituted (Figure 3). For internalizing targets, such as HER2, direct radioiodination methods are less appropriate, due to compromised cumulative radioactivity within the cell as a result of rapid excretion of the primary radiolabeled catabolites, e.g., iodotyrosines and free iodide, obtained by lysosomal degradation $[26,30]$.
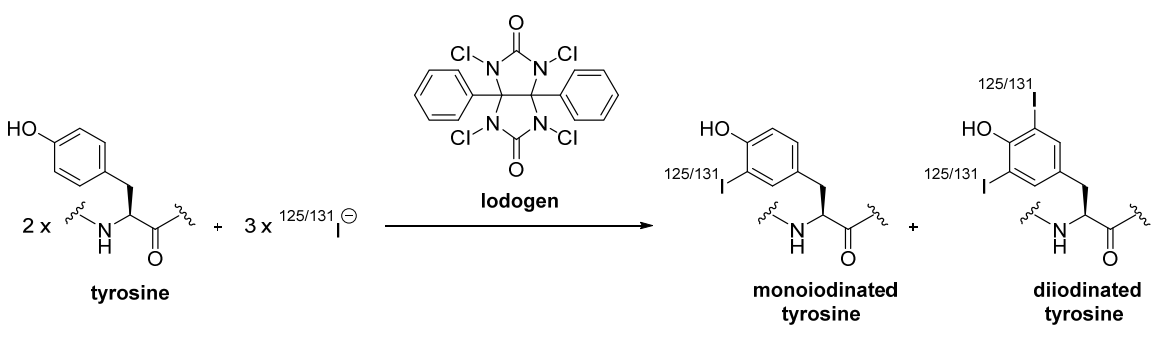

Figure 3. Installation of iodine-125 or iodine-131 into tyrosine residues of proteins and peptides via Iodogen [31].

\subsubsection{Indirect Radiohalogenation \\ Prosthetic Groups}

The same anti-HER2 nanobody (5F7) has been labeled with iodine-125 or iodine-131 by introducing $N^{\varepsilon}-\left(3-\left[{ }^{125 / 131} I\right]\right.$ iodobenzoyl)-Lys ${ }^{5}-N^{\alpha}$-maleimido-Gly ${ }^{1}$-GEEEK $\left(\left[{ }^{125 / 131} \mathrm{I}\right]\right.$ IB-Mal-D-GEEEK) (Figure 4) to sulfhydryl groups, which have been priorly installed on primary amines of the nanobody's amino acid sequence [26,27]. These include the $\varepsilon$-amino functionality of several lysines, but also the $N$-terminal $\alpha$-amino residue of the nanobody's peptide chain. Upon addition of the cyclic electrophile 2-iminothiolane, the nucleophilic amino groups are converted into amidines with a free thiol moiety as a result of ring opening [32]. In a Michael-type addition reaction, the thiol-derivatized nanobody can be further conjugated with the maleimide function of $\left[{ }^{125 / 131}\right.$ I]-IB-Mal-D-GEEEK. The structure of this prosthetic group is based on the peptide sequence Gly-D-Glu-D-Glu-DGlu-D-Lys-OH, in which the $\mathrm{N}$-terminal amino group of glycine is part of the maleimide and the $\varepsilon$-amino group of lysine is acylated by $3-\left[{ }^{125 / 131} \mathrm{I}\right]$ iodobenzoic acid. The three glutamic acids as well as the $C$-terminal lysine, all of which bear free carboxylic acid moieties, provide high polarity to the molecule. Apart from achiral glycine, all the amino acids within the pentapeptide are D-configured, rendering the sequence unsusceptible for proteolysis. Accordingly, such a prosthetic group is especially suited for radiolabeling structures that undergo intracellular processing, since it resists lysosomal digestion leading to a reduced efflux and thus to an increased retention inside the cell. Another way to trap radioactivity intracellularly is to apply radiohalogenated aromatic acylation agents comprising substituents, which remain charged at lysosomal $\mathrm{pH}$. These also include $\mathrm{N}$ succinimidyl 4-guanidinomethyl-3-[ ${ }^{125 / 131}$ I]iodobenzoate ([ ${ }^{125 / 131}$ I]SGMIB) as well as its 
isomer N-succinimidyl 3-guanidinomethyl-5-[ ${ }^{125 / 131}$ I]iodobenzoate (iso- $\left.\left[{ }^{125 / 131} \mathrm{I}\right] \mathrm{SGMIB}\right)$, differing from each other only in the substitution position of the highly basic guanidinomethyl moiety (Figure 4) $[27,33]$. Both prosthetic groups with their succinimide ester functionalities have been conjugated randomly to primary amines within 5F7. The conjugation reaction is usually performed in the range of $\mathrm{pH} 8-9$, at which the $\mathrm{N}$-terminal $\alpha$-ammonium (pKa 8) is largely deprotonated, while the $\varepsilon$-ammonium (pKa 10) is mostly protonated, rendering it less reactive towards the carbonyl carbon of the activated ester. For this reason, it is likely to obtain a mixture of radiotracers, in which only one or a few among all the existing amino groups within the nanobody are radiolabeled. Indirect radioiodination with $\left[{ }^{125}\right.$ I]SGMIB has been further conducted in order to label another anti-HER2 nanobody, 2Rs15d, binding to a target site distinct from that of 5F7 and thus allowing for imaging patients that are subjected to trastuzumab or pertuzumab therapy [34].

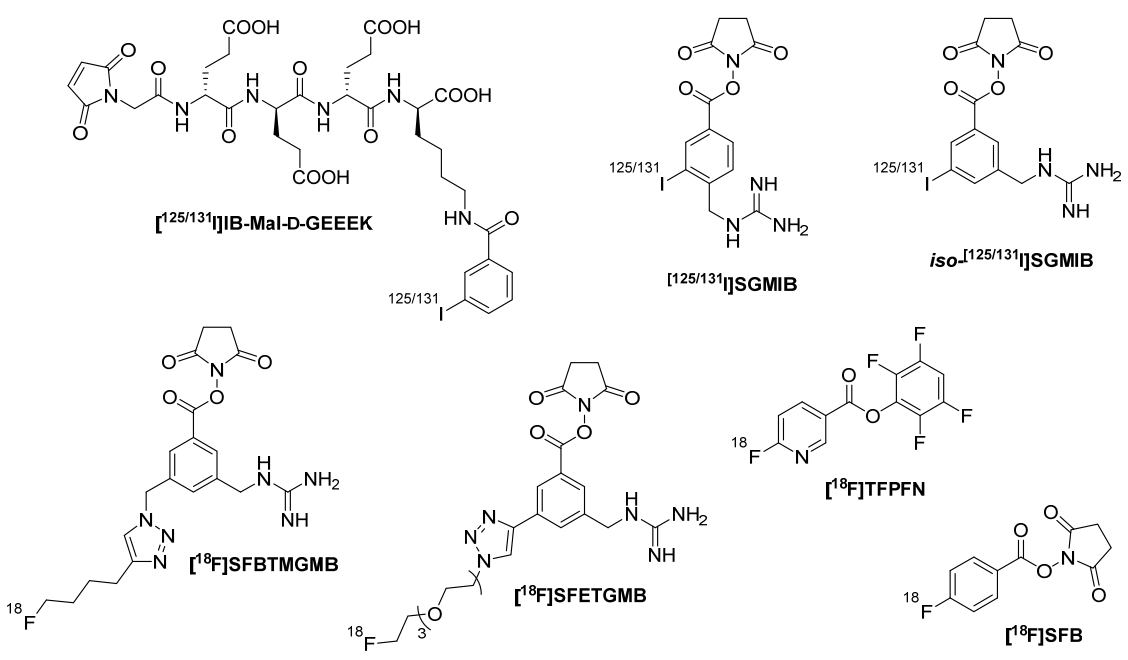

Figure 4. Radiohalogenated prosthetic groups which have been applied to nanobodies in a single final conjugation reaction.

Furthermore, both nanobodies were also envisaged for indirect radiofluorination. In order to obtain ${ }^{18} \mathrm{~F}$-containing prosthetic groups closely related to the guanidinomethylincorporating SGMIB, $N$-succinimidyl 3-((4-(4-[18 $\mathrm{F}]$ fluorobutyl)-1H-1,2,3-triazol-1-yl)methyl)5-(guanidinomethyl)benzoate ( $\left.\left[{ }^{18} \mathrm{~F}\right] \mathrm{SFBTMGMB}\right)$ and its analog $\mathrm{N}$-succinimidyl 3-(1-(2-(2-(2(2-[ $\left.{ }^{18} \mathrm{~F}\right]$ fluoroethoxy)ethoxy)ethoxy)ethyl)-1H-1,2,3-triazol-4-yl)-5-(guanidinomethyl)benzoate ( $\left[{ }^{18}\right.$ F]SFETGMB) (Figure 4) were synthesized through a multiple-step procedure involving copper(I)-catalyzed azide-alkyne cycloaddition (CuAAC) for the ${ }^{18}$ F-introduction almost at the very end, shortly prior to conjugation to primary amines of the nanobodies' peptide chain $[30,34,35]$. Nevertheless, the radiofluorinated nanobodies were achieved in very low overall decay-corrected radiochemical yields. Besides, Zhou et al. applied a different synthetic protocol, in which the click reaction was used for the attachment of the radiolabel to the nanobody [36]. In the first step, primary amines within $2 \mathrm{Rs} 15 \mathrm{~d}$ were pre-modified through an acylation reaction using $N$-succinimidyl 3-(azidomethyl)-5-(guanidinomethyl)benzoate (1) (Figure 5). Subsequently, the ${ }^{18}$ F-labeled aza-dibenzocyclooctyne derivative (2) was employed in order to conduct a strain-promoted azide-alkyne cycloaddition (SPAAC), yielding the desired radiotracer. Such copper-free click chemistry is especially suited for proteins, due to the avoidance of potential complex formation. Despite reducing the total radiosynthesis time by this approach, the overall radiochemical yield was still not satisfactory, tracing back to the lower reaction yield of SPAAC compared to CuAAC. Accordingly, improvements for both strategies need to be developed before application on a routine basis. 


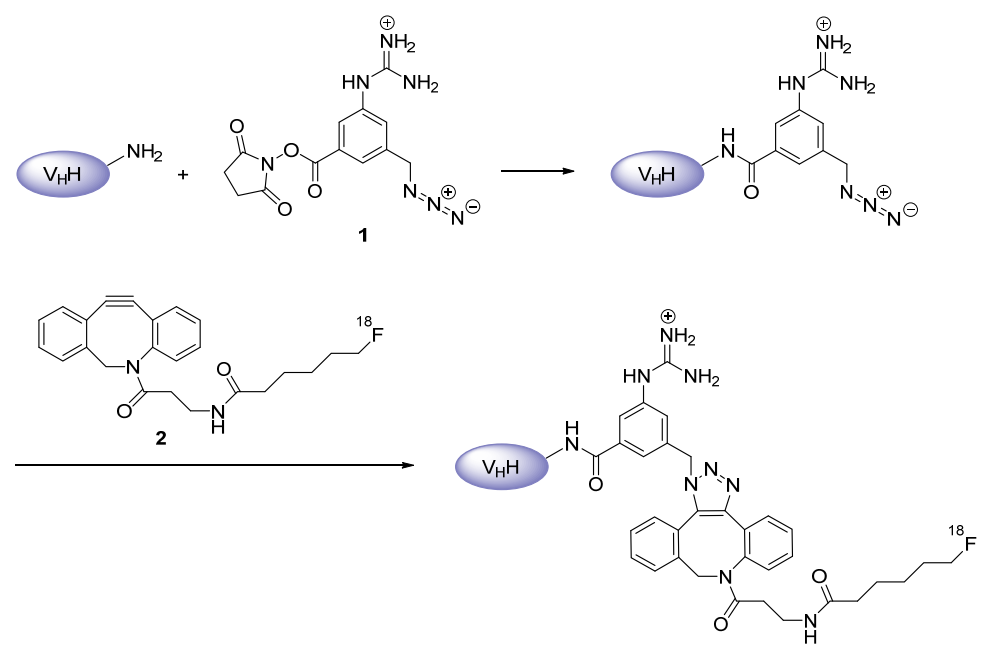

Figure 5. Pre-derivatization on primary amines of the nanobody with $\mathbf{1}$, followed by ${ }^{18} \mathrm{~F}$-introduction via 2 in a strain-promoted azide-alkyne cycloaddition reaction [36].

A certain limitation of these indirect methods for radiofluorinating the anti-HER2 nanobodies was the high kidney uptake of the radiotracers. Therefore, another ${ }^{18} \mathrm{~F}$-labeled prosthetic agent, namely 2,3,5,6-tetrafluorophenyl 6- $\left[{ }^{18} \mathrm{~F}\right]$-fluoronicotinate $\left(\left[{ }^{18} \mathrm{~F}\right] \mathrm{TFPFN}\right)$ (Figure 4), has been applied in order to radiolabel 2Rs15d and 5F7, respectively [37]. Its structure is based on a pyridine ring bearing the radiofluorine in position 6 and the carboxylic acid functionality in position 3, which in turn is activated as a 2,3,5,6tetrafluorophenyl ester, enabling the random conjugation to primary amines within the nanobodies' amino acid sequence. This molecule is closely related to the most commonly used prosthetic group for ${ }^{18} \mathrm{~F}$-labeling, $N$-succinimidyl-4- $\left[{ }^{18} \mathrm{~F}\right]$-fluorobenzoate $\left(\left[{ }^{18} \mathrm{~F}\right] \mathrm{SFB}\right)$ (Figure 4), differing from it only by the aromatic system, which herein is a benzene ring, and by the activated ester, i.e., a succinimide ester. Consequently, the attachment to both anti-HER2 nanobodies was conducted analogously $[3,30]$. Indeed, the introduction of these two very similar prosthetic groups to $5 \mathrm{~F} 7$ and $2 \mathrm{Rs} 15 \mathrm{~d}$ has proven valuable in terms of a lower renal uptake of the resulting radiotracers. Apart from HER2, $\left[{ }^{18} \mathrm{~F}\right] \mathrm{SFB}$ has been additionally used to radiofluorinate the two mouse-human cross-reactive nanobodies MMR 3.49 and cAbVCAM-1-5, specifically targeting the macrophage mannose receptor (MMR) and the vascular cell adhesion molecule (VCAM)-1, respectively [38,39]. Rashidian et al. described a very elegant method for radiofluorinating nanobodies (VHHDC13, VHH7, VHHDC8), which were specifically directed against the mouse cell surface marker CD11b or the mouse class II major histocompatibility complex (MHC) [40-42]. The two anti-class II nanobodies, VHH7 and VHHDC8, recognize a closely related epitope, but differ from each other in their affinity towards the target, which is 3-4 fold higher for VHHDC8 than for VHH7 [40]. These two as well as the anti-CD11b nanobody VHHDC13 were engineered in a way that they bore a sortase A-recognition motif (sortag), enabling C-terminal site-specific conjugation. The sortag itself embodies the oligopeptide Leu-Pro-Xxx-Thr-Gly (LPXTG), in which $\mathrm{Xxx}$ is any amino acid besides cysteine, and glycine is not the final $C$-terminal amino acid of the whole protein chain [43-45]. Sortase A is an enzyme found in Staphylococcus aureus that catalyzes transpeptidation reactions. Upon recognition, the thiol (-SH) of the transpeptidase's active-site cysteine nucleophilically attacks the carbonyl carbon $(\mathrm{C}=\mathrm{O})$ of the sortag's threonine, forming an acyl-enzyme intermediate (Figure 6). Subsequently, the carbonyl carbon of the thioester is nucleophilically attacked by the amino group of a different oligoglycine which is present in molar excess, preventing the reverse reaction. 


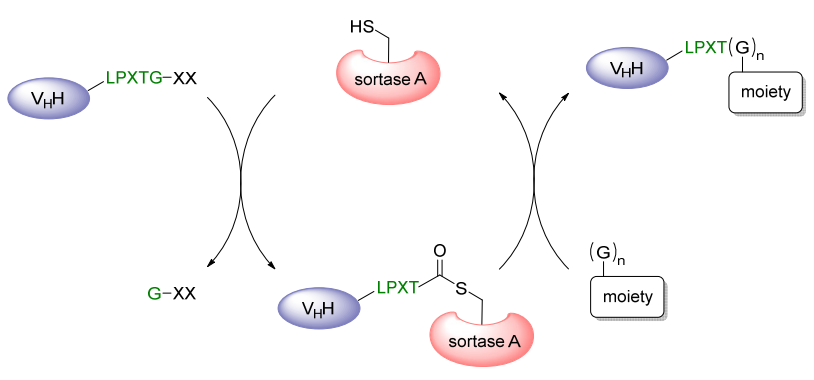

Figure 6. Reaction mechanism of the sortase A-mediated transpeptidation for labeling nanobodies site-specifically at the $C$-terminus [44]. LPXTG, sortase A-recognition motif; $X$, any amino acid except cysteine; $\mathrm{G}$, glycine; $\mathrm{SH}$, thiol function of the active site cysteine; $\mathrm{C}=\mathrm{O}$, carbonyl carbon of threonine.

Such $N$-terminal oligoglycines decorated with specific functionalities have been used by Rashidian et al. in order to site-specifically modify the three nanobodies so that an inverse-electron demand Diels-Alder (IEDDA) cycloaddition between a tetrazine and a trans-cyclooctene moiety could be employed for the installation of ${ }^{18} \mathrm{~F}$-containing prosthetic groups [40-42]. Firstly, the linker-connected triglycine-methyltetrazine compound 3 has been applied to introduce the tetrazine substructure at the $\mathrm{C}$-termini of VHH7 and VHHDC13 via sortase reaction, followed by the addition of the radiofluorinated trans-cyclooctene derivative 4 to obtain the desired radiotracers through IEDDA reaction (Figure 7) [41]. In a similar procedure, the trans-cyclooctene function has been sitespecifically inserted into VHH7 and VHHDC8 through their sortags by using the respective triglycine 5, while the tetrazine moiety for the click reaction was part of the ${ }^{18}$ F-incorporating prosthetic agent 6 (Figure 8), which itself was obtained via an oxime ligation reaction with commercially and widely available 2 -deoxy-2-[ $\left.{ }^{18} \mathrm{~F}\right]$ fluoro-D-glucose [40]. This approach has undergone further development to enable the indirect radiofluorination of homodimeric and pegylated forms of VHHDC13 and VHHDC 8 with the radiolabeled tetrazine 7 (Figure 9) [42]. Apart from the adjustment, the initial synthesis strategy using compounds 3 and $\mathbf{4}$ has been employed to three further recombinant nanobodies (A12, B3 and H11), from which A12 and B3 target the mouse programmed death ligand 1 (PD-L1) and H11 addresses the mouse cytotoxic T lymphocyte antigen (CTLA)-4 [46,47].

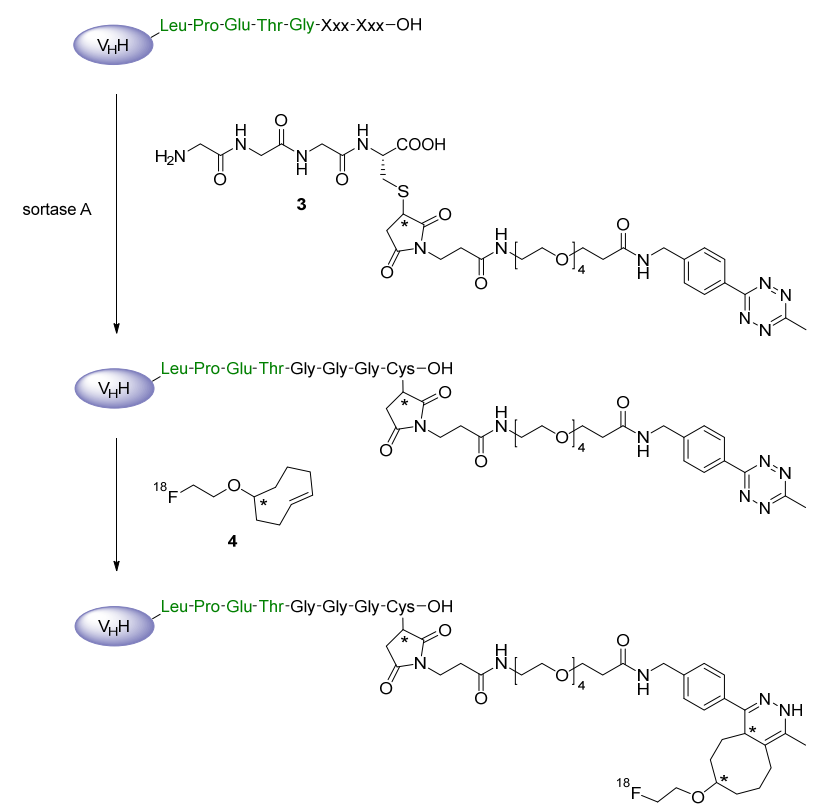

Figure 7. Site-specific insertion of $\mathbf{3}$ at the nanobody's $C$-terminus via sortase $A$ and subsequent inverse-electron demand Diels-Alder (IEDDA) cycloaddition with 4. 


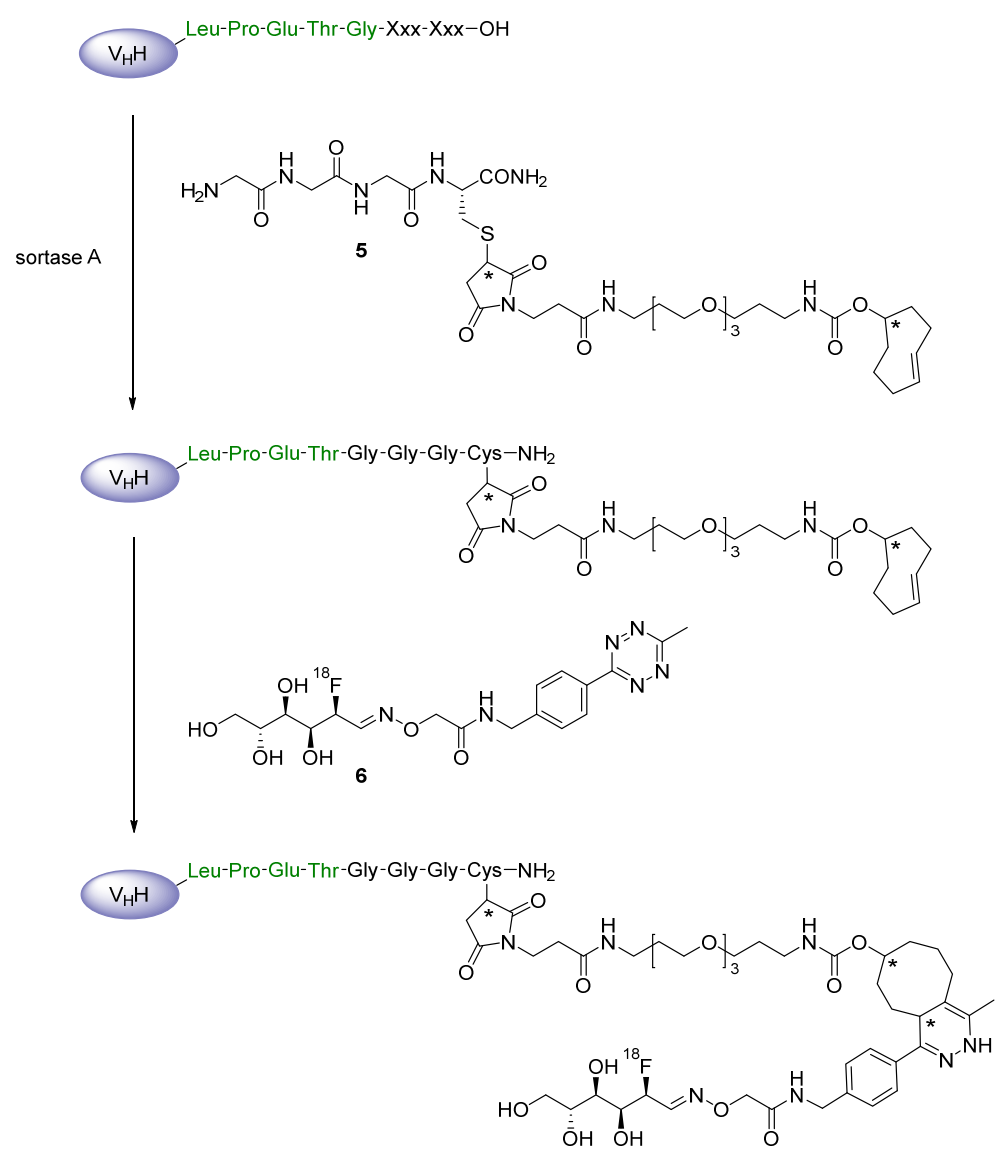

Figure 8. Sortase A-mediated C-terminal introduction of 5, followed by ${ }^{18}$ F-labeling with 6 in an IEDDA reaction.

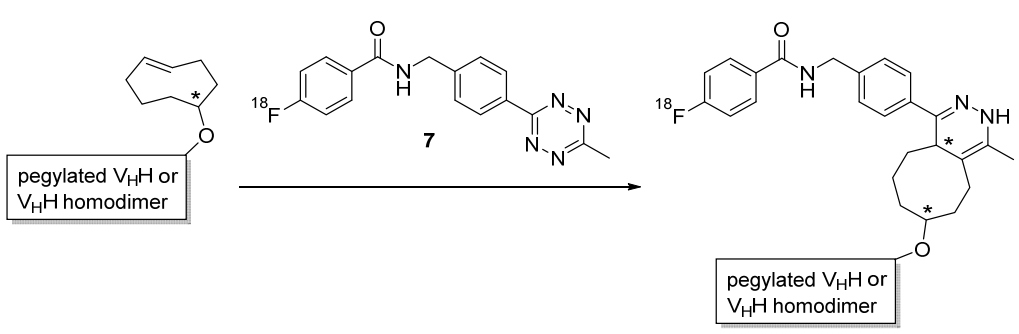

Figure 9. ${ }^{18}$ F-labeling of polyethylene glycol-functionalized or homodimeric nanobodies with 7 through IEDDA cycloaddition [42].

\section{Chelation}

Bifunctional chelating agents are very common for radiometal labeling, but their application can also be extended to radiofluorines. For this purpose, the radiofluoride is attached to a suitable metal, in particular aluminum, which itself is bound to an appropriate chelator conjugated to a targeting vehicle, altogether resulting in a stable complex [48]. Such an $A{ }^{18}$ F-labeling strategy has also been applied to the three nanobodies $2 \mathrm{Rs} 15 \mathrm{~d}$, cAbVCAM-1 -5 and NbV4m119, with the latter addressing the complement receptor of the immunoglobulin superfamily (CRIg) expressed on Kupffer cells [15,49-51]. Cleeren et al. established a new restrained complexing agent (RESCA) in order to facilitate the chelation reaction with aluminum mono $\left[{ }^{18} \mathrm{~F}\right]$ fluoride $\left(\left[{ }^{18} \mathrm{~F}\right]\{\mathrm{AlF}\}^{2+}\right)$ at room temperature, which is particularly suited for heat-sensitive biomolecules, e.g., nanobodies (Figure 10) [49,50]. Prior to complexation, the acyclic pentadentate chelator $( \pm)-\mathrm{H}_{3}$ RESCA was randomly introduced to primary amines of the two nanobodies via the activated form, bearing a 2,3,5,6-tetrafluorophenyl ester $\left(( \pm)-\mathrm{H}_{3}\right.$ RESCA-TFP). Zhou et al. followed a more lengthy 
but elegant approach to radiolabel the $2 \mathrm{Rs} 15 \mathrm{~d}$ nanobody with aluminum mono $\left[{ }^{18} \mathrm{~F}\right]$ fluoride via the macrocycle 1,4,7-triazacyclononane- $N, N^{\prime}, N^{\prime \prime}$-triacetic acid (NOTA) [15]. By using the IEDDA reaction in tandem with a renal BBE-cleavable glycine-lysine (GK) linker in the prosthetic moiety, a good labeling yield as well as a low uptake of ${ }^{18}$ F-activity in the kidneys was achieved. For this purpose, the trans-cyclooctene moiety was introduced to $2 \mathrm{Rs} 15 \mathrm{~d}$ by randomly reacting the nanobody's primary amines with the succinimide ester of TCO-GK-PEG 4 -NHS (8), which was then clicked to $\left[{ }^{18} \mathrm{~F}\right]$ AlF-NOTA-PEG 3 -methyltetrazine (9) to yield the final tracer (Figure 11). Short polyethylene glycol (PEG) chains consisting of three and four units, respectively, have been implemented not only to further reduce the kidney uptake, but also to provide structural flexibility to the molecule in order to enable an enhanced enzyme accessibility to the cleavable GK linker. Although low kidney activity levels were accomplished, tumor uptake was impaired, which was not related to the tracer's $\left[{ }^{18} \mathrm{~F}\right]$ AlF-NOTA moiety, since its replacement by a prosthetic group did not remedy the problem [52]. All in all, compared to the other indirect radiofluorination strategies, the $\mathrm{Al}^{18} \mathrm{~F}$-chelation technique allows for higher radiochemical yields in a substantial shorter synthesis time, which is a key advantage of chelator-based radiolabeling methods $[15,49,50]$.

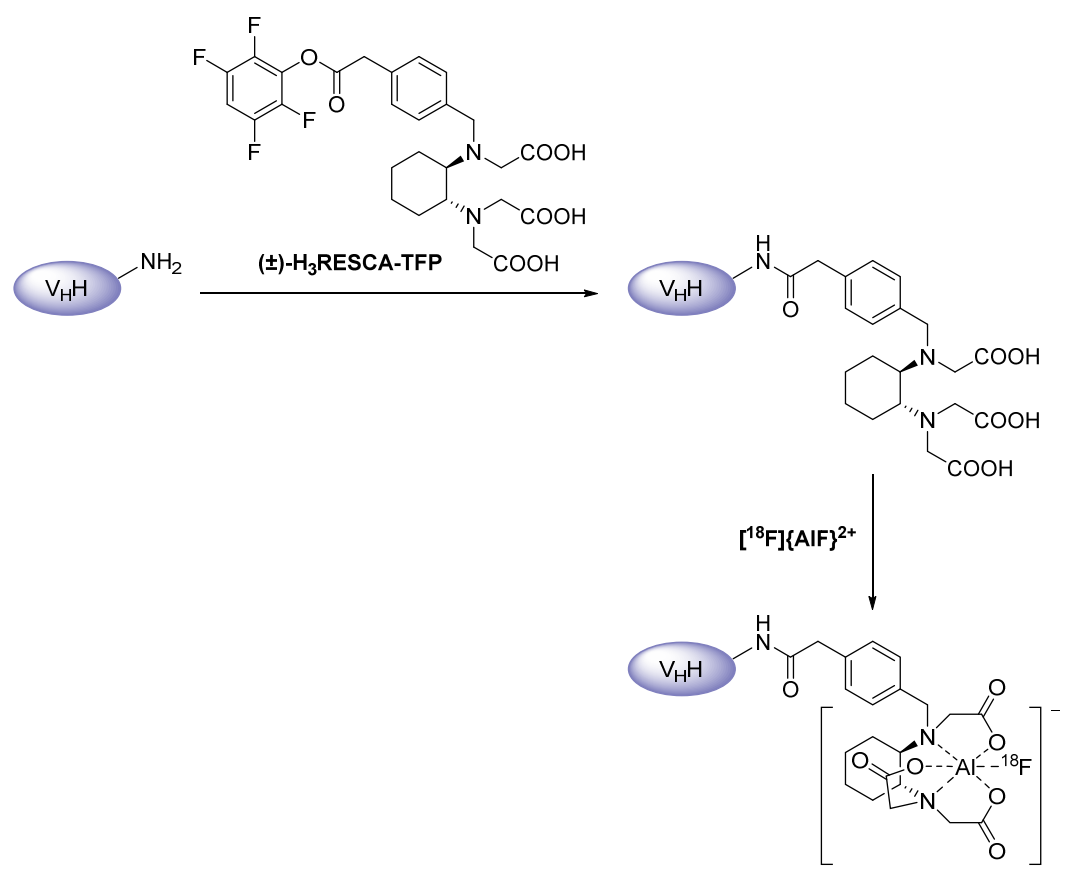

Figure 10. Conjugation of $( \pm)-\mathrm{H}_{3}$ RESCA-TFP to primary amines of the nanobody, followed by $\mathrm{Al}^{18}$ F-labeling $[49,50]$. 


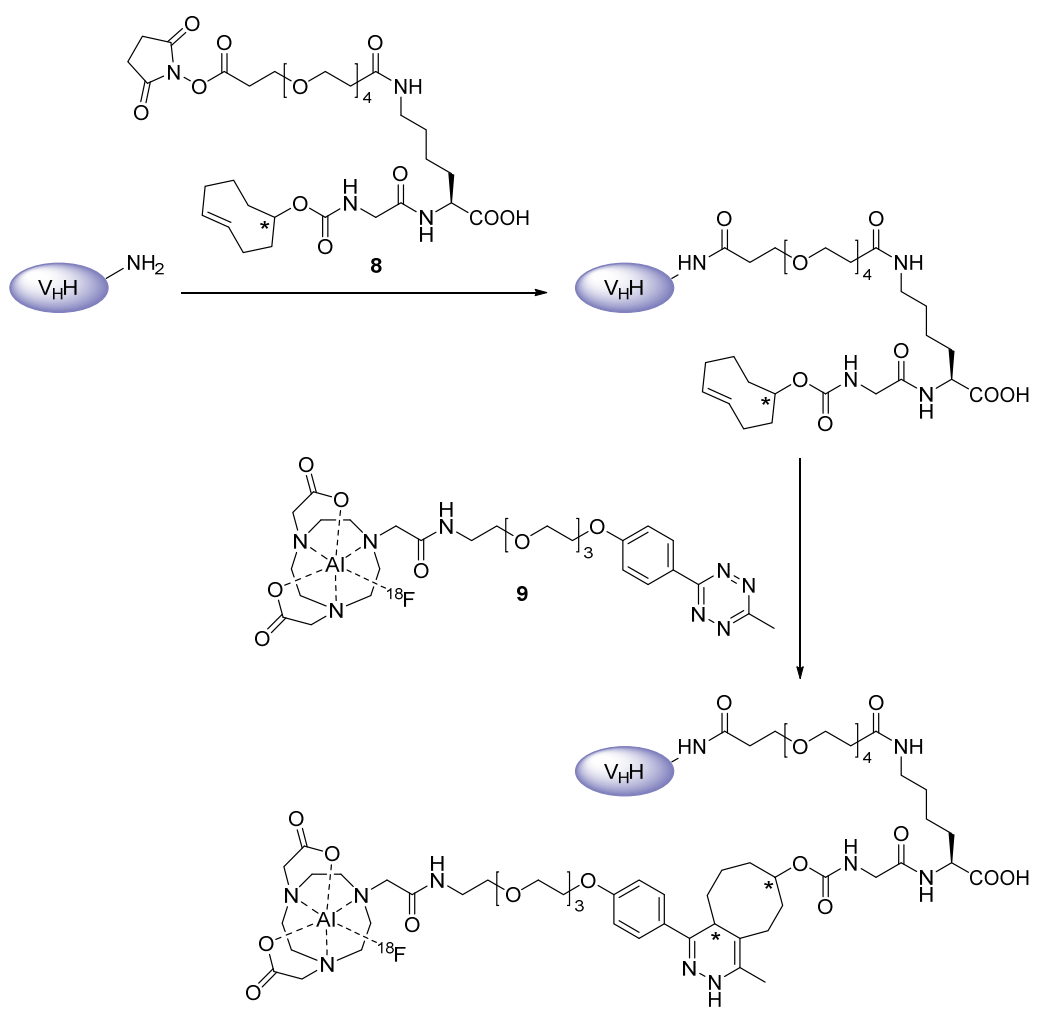

Figure 11. Pre-derivatization on primary amines of the nanobody with $\mathbf{8}$, followed by ${ }^{18}$ F-labeling with 9 via IEDDA reaction [15].

\subsection{Radiometals}

Radiometal labeling is also based on chelation and represents an attractive alternative to radiohalogenation [53]. Owing to its simplicity, reproducibility and high efficiency, this method can be easily implemented in clinical routine. Among the common PET radiometals, gallium-68 is very convenient because of its simple, cyclotron-independent production via germanium-68/gallium-68 generators [12,54]. It also exhibits a short halflife of $67.7 \mathrm{~min}$, along with a low positron energy as well as a high positron yield; the latter reflects a major decay through positron emission. In contrast, copper-64 and zirconium-89 constitute radiometals with supplemental alternative decay pathways, requiring higher administration doses because of lower sensitivity. Additionally, both radionuclides have much longer half-lives (12.7 h for copper-64 [55]; $78.4 \mathrm{~h}$ for zirconium-89 [56]), rendering them less appropriate for nanobody radio imaging. This also applies to the gamma-emitting radiometals indium-111 and lutetium-177, which possess a half-life of $67.2 \mathrm{~h} \mathrm{[57]} \mathrm{and}$ 6.65 days [58], respectively. Furthermore, lutetium-177 is mainly applied for therapeutic purposes due to the emission of low-energy $\beta$-minus particles [59]. Hence, much more

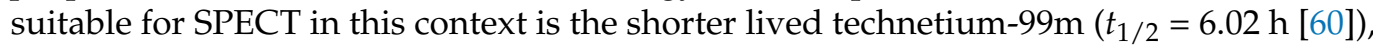
which can also be easily obtained from widespread molybdenum- $99 /$ technetium- $99 \mathrm{~m}$ generators [61].

\subsubsection{Synthetic Chelators}

The majority of chelating agents are produced by means of organic chemistry. The applied bifunctional chelators (BFCs) bear a chemically reactive functional group for attachment to the targeting vehicle on the one hand, and a metal binding moiety for sequestration of the metallic radionuclide on the other hand [13].

\section{Macrocyclic}

Among the different available macrocyclic chelators, almost exclusively NOTA has been used for radiolabeling nanobodies. This hexadentate ligand is especially suited for 
such heat-labile proteins, due to the rapid and highly efficient complexation of copper-64 and gallium-68 at room temperature [54]. Site-specific labeling with copper-64 has been conducted by introducing GGGC-NOTA (Figure 12) to the $C$-termini of several nanobodies (B3, VHH7, VHHDC13, VHH4, NJB2) via sortase A-mediated reaction, followed by radiometal chelation, as common in post-labeling strategies $[41,46,62,63]$. Its molecular structure is based on the tetrapeptide sequence H-Gly-Gly-Gly-Cys- $\mathrm{NH}_{2}$, in which the cysteine's thiol function is covalently linked to maleimide-NOTA. Unlike the anti-mouse class II MHC nanobody VHH7, VHH4 targets human class II MHC products [62]. NJB2 is a mouse-human cross-reactive nanobody specific to an alternatively spliced domain of fibronectin expressed in disease extracellular matrix and neo-vasculature [63]. For random ${ }^{64} \mathrm{Cu}$-labeling, different nanobodies (Lox1.14, MMR 3.49, cAbVCAM-1-5) have been decorated with 2-S-(4-isothiocyanatobenzyl)-NOTA ( $p$-SCN-Bn-NOTA) (Figure 12) [64], a BFC that bears an isothiocyanate functionality, enabling the reaction with primary amines of the amino acid sequence. Apart from Lox1.14 targeting the lectin-like oxidized low-density lipoprotein receptor (LOX)-1, the same BFC has been utilized for unselective ${ }^{68} \mathrm{Ga}$-labeling of the other two nanobodies (MMR 3.49, cAbVCAM-1-5) [64-66], plus eight further nanobodies (2Rs15d, 4hD29, 9077, 9079, Nb109, K2, Nb1053, SNA006a) [54,67-72], with 9077 and 9079 both addressing the cell surface marker CD20 [71], Nb109 and K2 both being directed against human PD-L1 [69,70], as well as Nb1053 and SNA006a targeting CD38 and CD8, respectively $[67,68]$. Moreover, in GGGYK-NOTA (Figure 12), $p$-SCN-Bn-NOTA has been attached to the $\varepsilon$-amino group of the $C$-terminal lysine as part of the pentapeptide H-Gly-Gly-Gly-Tyr-Lys- $\mathrm{NH}_{2}$ in order to allow also for site-specific ${ }^{68} \mathrm{Ga}$-labeling of 2Rs15d, cAbVCAM-1-5 and K2 [18,66,69]. However, the direct comparison with their randomly-labeled counterparts revealed no significant differences with regard to targeting efficacy determined for 2Rs15d in in vitro cell binding assays, biodistribution ascertained for cAbVCAM-1 -5 in ex vivo experiments, and tumor uptake investigated for $\mathrm{K} 2$ in in vivo studies. Besides the sortase A enzyme approach, site-specific ${ }^{68} \mathrm{Ga}$-labeling of $\mathrm{K} 2$ was also realized through maleimide-NOTA (Figure 12) conjugated to a cysteine engineered to the nanobody's C-terminus [73]. Prior to the Michael addition reaction, however, mild reducing conditions were applied in order to particularly free the $C$-terminal thiol group from disulfides formed by dimerization or glutathione-capping, while leaving internal cysteines that are essential for the nanobody's tertiary structure intact.

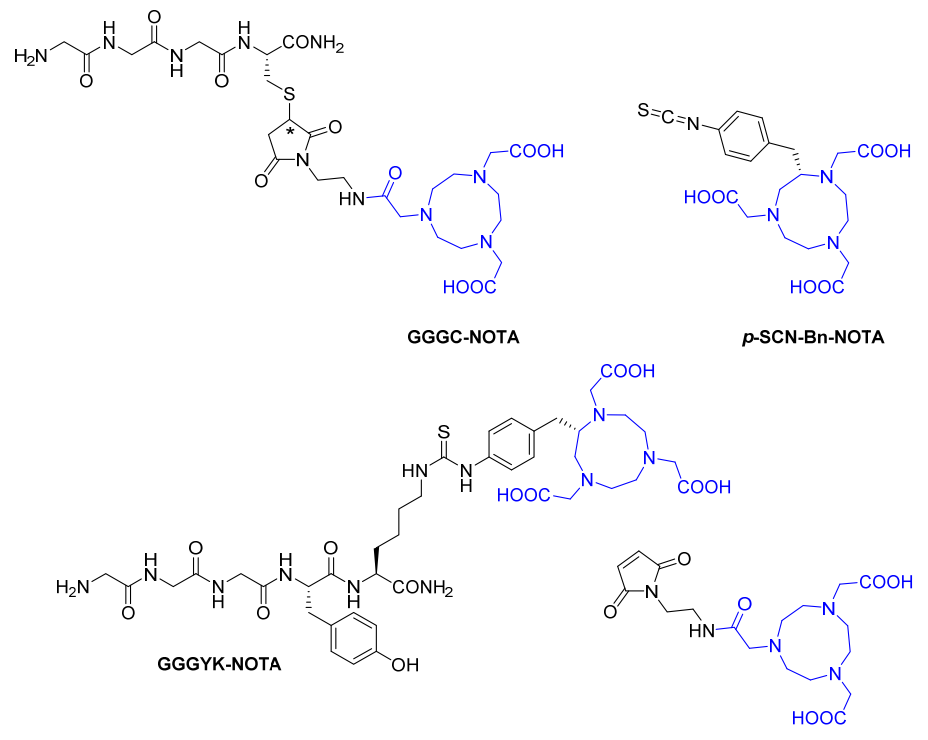

maleimide-NOTA

Figure 12. 1,4,7-Triazacyclononane- $N, N^{\prime}, N^{\prime \prime}$-triacetic acid (NOTA)-based synthetic chelators applied to nanobodies for radiometal labeling. NOTA substructure is highlighted in blue. 
Acyclic

The acyclic chelator desferrioxamine $\mathrm{B}(\mathrm{DFO})$ is a naturally occurring siderophore that bears hydroxamate functions for complexing radiometals [12,74]. In the form of the BFC $\mathbf{1 0}$ bearing a reactive isothiocyanate group (Figure 13), DFO has been randomly conjugated to primary amines of the anti-HER1 nanobody 7D12 to facilitate its radiolabeling with gallium-68 or zirconium-89 [74,75]. The same BFC has also been used for unselective ${ }^{89} \mathrm{Zr}$ labeling of the anti-gelsolin nanobody NB11 on the one hand, and of the two nanobody heterodimers 1E2-Alb8 and 6E10-Alb8 on the other hand [76,77]. In the latter two cases, nanobodies (1E2, 6E10) targeting the hepatocyte growth factor have been linked to an albumin-binding nanobody unit (Alb8) in order to extend the circulation time [76]. A similar concept has been realized in nanobody construct MSB0010853 consisting of three interconnected, mouse-human cross-reactive nanobodies, out of which one is specifically directed against albumin and two address the target HER3 at distinct epitopes [78]. While usually in post-labeling methods the chelating unit is empty when the BFC is attached to the nanobody, for pre-modification of MSB0010853, TFP-N-suc-DFO-Fe (Figure 13) has been applied, in which the hydroxamate groups have been temporarily blocked with the trivalent iron cation [78]. After randomly reacting its 2,3,5,6-tetrafluorophenyl ester with the construct's primary amines, the iron was efficiently detached from DFO and subsequently labeled with zirconium-89 leading to the desired radio-probe.

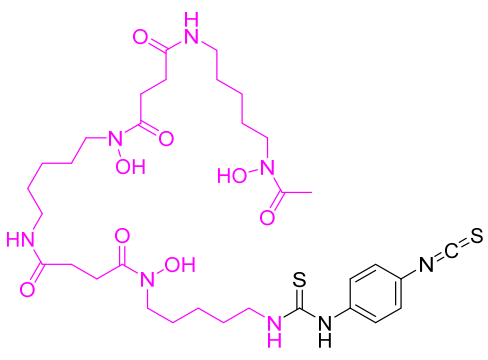

10

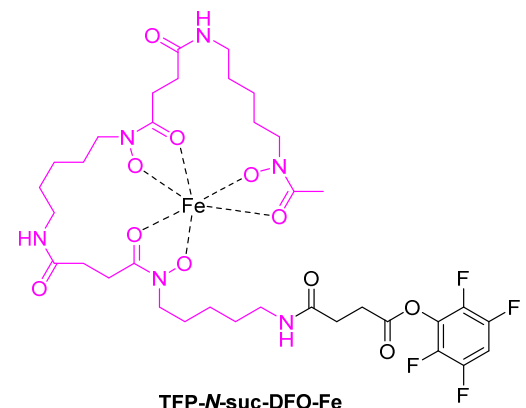

TFP-N-suc-DFO-Fe<smiles>CC(=O)N(O)CCCCCNC(=O)CCC(=O)N(O)CCCCCNC(=O)CCC(=O)N(O)CCCCCNC(=O)CCN1C(=O)CC(SC[C@H](NC(=O)CNC(=O)CNC(=O)CN)C(N)=O)C1=O</smiles><smiles>CCN(O)C(=O)CCC(=O)NCCCCCN(O)C(=O)CCC(=O)NCCCCCN(O)C(C)=O</smiles>

GGGC-DFO<smiles>NCCCCC(NC(=O)CCOCCNC(=O)C(CSC1=CC(=O)N(CCCN)C1=O)NC(=O)CCOCCNC(=O)CNC(=O)CNC(=O)CN)C(N)=O</smiles>

11

Figure 13. Desferrioxamine B (DFO)-based synthetic chelators used for radiometal labeling of nanobodies. DFO substructure is highlighted in pink.

Moreover, site-specific ${ }^{89} \mathrm{Zr}$-labeling has been conducted on nanobody VHH-X118 targeting the mouse cell surface marker CD8 $[79,80]$. Initially, the tetrapeptide-based sortase A substrate GGGC-DFO (Figure 13) was ligated to the C-terminus, which itself was obtained from the addition reaction between the cysteine's thiol and the maleimide of functionalized DFO. Furthermore, with compound 11 (Figure 13), a pegylated version of the substrate was established. Therein, a carboxyl-to-amine linker containing three 
PEG units was introduced between the triglycine and the cysteine on the one hand, and at the cysteine's terminal carboxamide group on the other hand, where it was further extended by a modified lysine bearing a $C$-terminal carboxamide and an $\varepsilon$-azide group. After selective conjugation of $\mathbf{1 1}$ to $\mathrm{VHH}-\mathrm{X} 118$, the azide click handle allowed for the additional introduction of PEG units via SPAAC, followed by ${ }^{89} \mathrm{Zr}$-complexation. The resulting radiotracers exhibited an improved image quality compared to the non-pegylated counterpart, due to the prolonged plasma half-life along with the reduced accumulation in elimination organs. Hence, another nanobody, i.e., H11, was also site-specifically labeled with zirconium-89 by following this pegylation strategy [47].

Diethylenetriaminepentaacetic acid (DTPA) is one of the oldest acyclic chelators, which is clinically widely established and valued for its well defined labeling techniques enabling facile and stable incorporation of indium-111 and lutetium-177 even at room temperature [81-83]. As part of maleimide-DTPA (Figure 14), it has been utilized for site-specific ${ }^{111}$ In-labeling of three nanobodies, i.e., 2Rs15d, JVZ-007 and 4hD29, with the latter two being specific to the prostate-specific membrane antigen (PSMA) and the enzyme dipeptidyl-peptidase 6 , respectively $[16,82,84]$. For this purpose, the C-termini of these three nanobodies were engineered to bear a cysteine, which due to spontaneous oxidative homodimerization required mild reducing conditions to specifically free this thiol for the Michael addition reaction with the maleimide moiety on the one hand, but maintaining the intradomain disulfide bridges on the other hand. Furthermore, the BFC $p$-SCN-Bn-DTPA (Figure 14) has been randomly introduced to primary amines of JVZ-007 as well as of the amyloid-targeting nanobody $\mathrm{VHH}$-pa2H, in order to allow for ${ }^{111}$ In-chelation [82,83]. CHX-A"-DTPA (Figure 14) represents a structural analog of $p$-SCN-Bn-DTPA, in which the non-benzyl substituted flexible ethylene backbone is fixated by a butane chain forming a six-membered ring [81]. Such cyclohexyl moiety imparts a higher degree of rigidity to the chelating unit and with that an imposed preorganization on the metal ion binding site leading to an enhanced kinetic inertness of the radiometal complex. By fusing CHX$\mathrm{A}^{\prime \prime}$-DTPA with its isothiocyanate group to the lysine's $\varepsilon$-amino group of the pentapeptide H-Gly-Gly-Gly-Tyr-Lys-NH ${ }_{2}$ as in GGGYK-CHX-A"-DTPA (Figure 14), site-specific ${ }^{111}$ Inlabeling of the two nanobodies 2Rs15d and cAbVCAM-1-5 has been realized [18,66]. CHXA"-DTPA has also been directly applied to primary amines of these nanobodies for random incorporation of indium-111 [18,66,85]. However, head-to-head comparison with the selective ${ }^{111}$ In-tracers did not reveal a significant difference with respect to targeting efficacy of 2Rs15d and biodistribution of cAbVCAM-1-5. Based on nanobody 9077, different constructs have been developed including monomeric, homodimeric and heterodimeric structures, which were randomly decorated with $\mathrm{CHX}-\mathrm{A}^{\prime \prime}$-DTPA through their primary amines in order to allow for ${ }^{111} \mathrm{In}$ - and ${ }^{177}$ Lu-labeling, respectively [86]. In the same way, nanobody 9079 in its monomeric form has been radiolabeled with lutetium-177 [71]. 1B4M-DTPA (Figure 14), also known as tiuxetan, is structurally even closer to $p$-SCNBn-DTPA than CHX-A"-DTPA, differing from it only by a single methyl group situated on the outer carbon of the non-benzyl substituted ethylene backbone [81]. This BFC has been randomly employed to primary amines of the two nanobodies 2Rs15d and R3B23 to enable ${ }^{177} \mathrm{Lu}$-chelation $[59,85,87]$. The latter displays a very specific nanobody, targeting the monoclonal idiotype present in the murine 5T2MM model (5T2MMid), which itself is a syngeneic immunocompetent model resembling human multiple myeloma clinically and biologically [59]. 


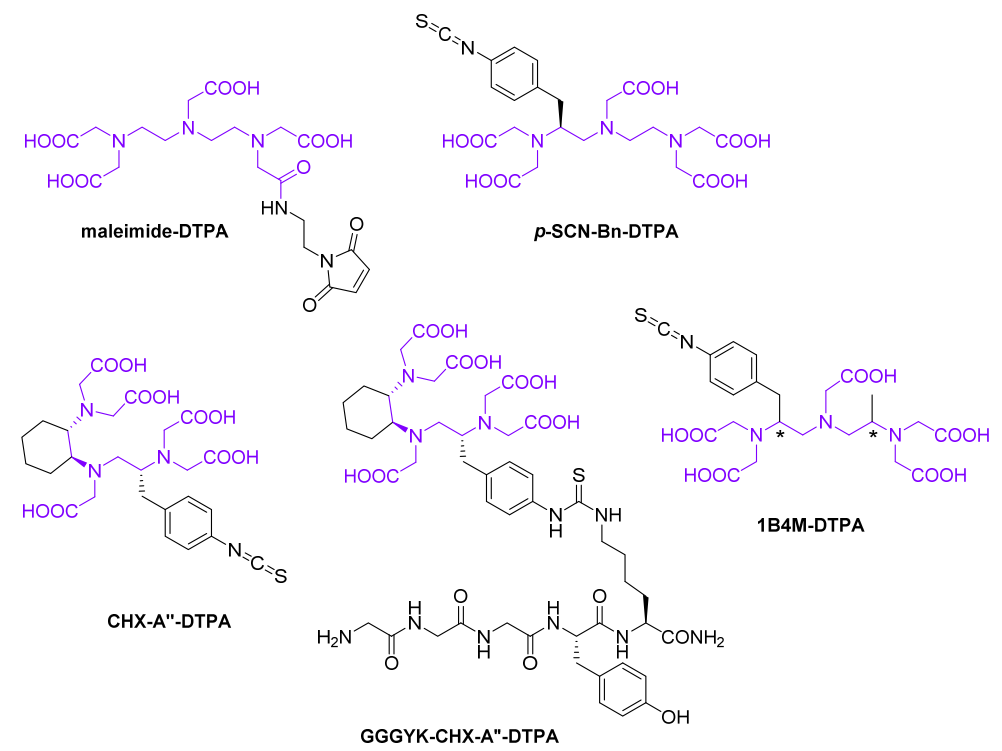

Figure 14. Diethylenetriaminepentaacetic acid (DTPA)-based synthetic chelators employed for labeling nanobodies with radiometals. DTPA substructure is highlighted in violet.

\subsubsection{Proteinogenic Chelator}

Besides the attachment of synthetic chelators and thereby chemical modification of the nanobodies' molecular structure, a certain part of their amino acid sequence offers a very convenient and site-specific labeling technique [18]. In fact, a $C$-terminal hexahistidine $\left(\mathrm{His}_{6}\right)$ tail is usually genetically engineered in order to facilitate the purification of the protein on a nickel affinity column $[54,61]$, which also enables the incorporation of technetium-99m in the form of ${ }^{99 \mathrm{~m}} \mathrm{Tc}$-tricarbonyl $\left.\left(\left[{ }^{99 \mathrm{~m}} \mathrm{Tc}\right] \mathrm{Tc}\left(\mathrm{H}_{2} \mathrm{O}\right)_{3}(\mathrm{CO})_{3}\right]^{+}\right)[16,88]$. The tricarbonyl core is efficiently coordinated by three of the total of six histidine-derived imidazole residues, forming the basis for this elegant method (Figure 15) [61]. Since the $\mathrm{His}_{6}$-tag is located on the opposite side of the paratope, the antigen-binding activity remains usually unaffected $[13,61]$. This labeling strategy has been applied not only to a huge panel of nanobodies addressing the so far discussed targets, e.g., HER-1 [89], MMR [53,90,91], VCAM-1 [92,93], PD-L1 [94,95], CRIg [96], LOX-1 [97], gelsolin [98,99], PSMA [100], amyloid [101], but also to several nanobodies that are directed against other structures, such as carcinoembryonic antigen (CEA) [102], mesothelin [103], CD33 [88], murine bone marrow-derived dendritic cells [104], mouse C-type lectin domain family 4 member F (Clec4F) [105], and mouse lymphocyte-activation gene 3 (LAG-3) [106,107]. However, such an additional $\mathrm{His}_{6}$-tag implies disadvantages with respect to clinical application, comprising induction of immune responses on the one hand [108,109], and high kidney retention on the other hand [54]. Accordingly, in the context of multiple imaging modalities, ${ }^{99 \mathrm{~m}}$ Tc-tricarbonyl-labeled nanobodies display a rather limited scope [18].

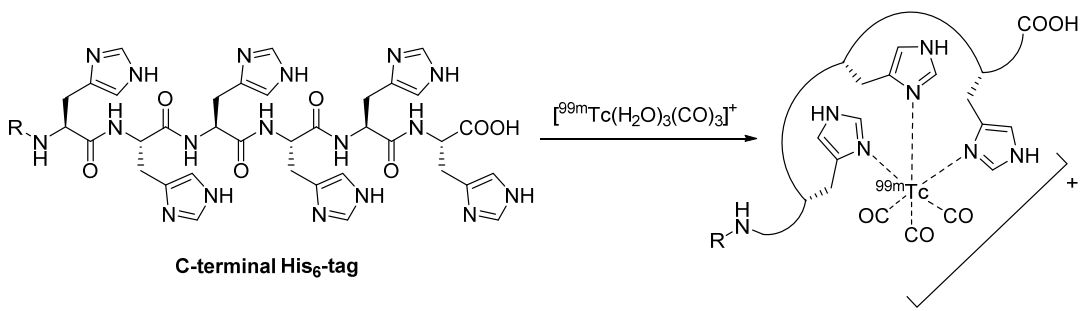

Figure 15. Complex formation between a C-terminal hexahistidine-tag and ${ }^{99 \mathrm{~m}}$ Tc-tricarbonyl [110].

\subsubsection{Heteroleptic Complex}

Another way to radiolabel nanobodies with technetium-99m has been described by Gao et al. [111]. Therein, prior to attachment to the murine (MY1523) and the hu- 
man (NB17) PD-L1-targeted nanobody, respectively, the heteroleptic complex consisting of technetium-99m coordinated by the three ligands GGGGK(HYNIC), triphenylphosphine$3,3^{\prime}, 3^{\prime \prime}$-trisulfonic acid trisodium salt (TPPTS) and tricine was formed (Figure 16). GGGGK(HYNIC) is based on the pentapeptide H-Gly-Gly-Gly-Gly-Lys-OH, in which the $\varepsilon$-amino group of the $C$-terminal lysine is acylated by 6-hydrazinonicotinic acid. While the hydrazine moiety takes part in the complex formation, the tetraglycine identifies the molecule as a substrate for sortase A, thereby enabling the label installation.

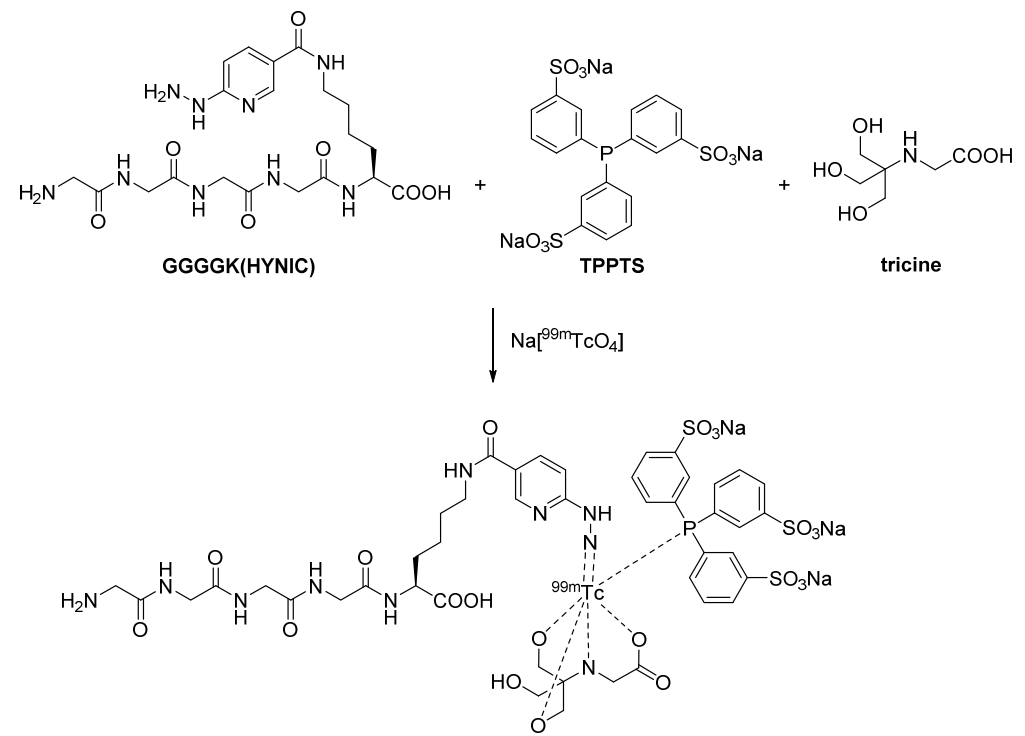

Figure 16. Assumed complex formation of technetium-99m coordinated by three ligands [112].

\section{Conclusions}

With the introduction of new tracers, molecular nuclear imaging has become increasingly important in recent years [113]. While success was often achieved with small molecules as radiolabeled ligands for PSMA [114], nanobody-based radio-probes are coming more and more to the fore in current research $[69,115]$. During the past twelve years, many different strategies for radiolabeling nanobodies have been implemented (Table 1), including both radiohalogens and radiometals, which have been introduced randomly or site-specifically to the nanobodies' peptide chain. Among these, the most convenient method is certainly the site-specific ${ }^{99 \mathrm{~m}}$ Tc-labeling through an engineered $\mathrm{His}_{6}$-tag. However, with respect to clinical diagnostics, the other techniques are much more favorable. Even though chelator-based radiolabeling of nanobodies appears to dominate currently, it still remains to be seen which of all of the approaches described herein will prevail henceforth.

Future applications of radiolabeled nanobodies may range from oncological questions, such as tumor specific receptor statuses, to the visualization of cardiovascular or neurological diseases. One of the first targets investigated was the HER2 receptor status in breast cancer patients, which is a crucial point for the treatment of these patients when suffering from advanced disease [27]. In the context of receptor status in oncology, heterogeneity is also an important topic and an essential question for molecular imaging, as this cannot be assessed by biopsy of single lesions, which is nowadays often used for treatment planning [116]. In addition, in many other tumor entities, heterogeneity seems to be a key factor in connection with treatment planning, as e.g., in melanoma [117], or as a potential surrogate marker in liver tumors or liver metastases [118]. Accordingly, it is also a major point to examine tumor heterogeneity in other pathological markers such as PD-L1, which also represents a pivotal target for nanobody-based imaging [95]. This, of course, needs to be discussed in association with quantitative molecular imaging and its limitations such as spatial resolution and the need for standardization of scanners and imaging protocols [119]. Moreover, immunological processes can be investigated in much 
more detail with radiolabeled nanobodies than with conventional radiotracers, which are certainly able to provide some basic information [120], but are limited in specificity. This is also of great interest in terms of cardiovascular diseases [121].

Table 1. Pros and Cons of the herein discussed radiolabeling techniques applied to nanobodies.

\begin{tabular}{|c|c|c|c|}
\hline Radiolab & Strategies & Positive Aspects & Negative Aspects \\
\hline \multirow{3}{*}{ Radiohalogens } & Iodogen & $\begin{array}{l}\text { sufficiently mild method to directly } \\
\text { radioiodinate sensitive proteins at low } \\
\text { temperatures }\end{array}$ & $\begin{array}{l}\text { solely unspecific labeling possible } \\
\text { limited to radioiodines }\end{array}$ \\
\hline & Prosthetic groups & $\begin{array}{l}\text { labeling with different radiohalogens } \\
\text { feasible } \\
\text { huge variety in their design realizable }\end{array}$ & $\begin{array}{c}\text { their preparation and purification are } \\
\text { usually sophisticated resulting in a long } \\
\text { labeling procedure and low chemical } \\
\text { yields }\end{array}$ \\
\hline & Chelation & $\begin{array}{l}\text { simplified labeling process leading to } \\
\text { good radiochemical yields as well as } \\
\text { high molar activities }\end{array}$ & $\begin{array}{l}\text { only applicable to fluorine- } 18 \\
\text { radioactivity is not introduced in the } \\
\text { final step }\end{array}$ \\
\hline \multirow{5}{*}{ Radiometals } & \multirow[b]{2}{*}{ Synthetic chelators } & radiolabel is inserted at the very end & $\begin{array}{l}\text { consistently metal-free conditions } \\
\text { essential }\end{array}$ \\
\hline & & $\begin{array}{l}\text { different radiometals are introducible } \\
\text { to the same chelator }\end{array}$ & $\begin{array}{l}\text { can affect the physicochemical } \\
\text { properties of the nanobody }\end{array}$ \\
\hline & \multirow{2}{*}{$\begin{array}{l}\text { Proteinogenic } \\
\text { chelator }\end{array}$} & $\begin{array}{l}\text { chelator is often engineered for } \\
\text { purification reasons }\end{array}$ & induction of immune responses \\
\hline & & $\begin{array}{l}\text { enables site-specific labeling with } \\
\text { technetium- } 99 \mathrm{~m}\end{array}$ & $\begin{array}{l}\text { 99m Tc-tricarbonyl }{ }^{\#} \text { required, which has } \\
\text { to be prepared }\end{array}$ \\
\hline & $\begin{array}{l}\text { Heteroleptic } \\
\text { complex }\end{array}$ & $\begin{array}{c}\text { no conversion of technetium-99m } \\
\text { necessary }\end{array}$ & $\begin{array}{c}\text { radiocomplex needs to be formed prior } \\
\text { to attachment }\end{array}$ \\
\hline
\end{tabular}

All in all, nanobodies seem to constitute a powerful and safe tool for the development of new radiopharmaceuticals for various applications. For imaging purposes, there is a high variety of intriguing labeling strategies, as outlined in this review.

Funding: This research was funded by the Deutsche Forschungsgemeinschaft (DFG, German Research Foundation) under Germany's Excellence Strategy-EXC2151-390873048.

Institutional Review Board Statement: Not applicable.

Informed Consent Statement: Not applicable.

Data Availability Statement: Not applicable.

Conflicts of Interest: R.A.B. is Consultant for Bayer Healthcare (Leverkusen, Germany) and Eisai $\mathrm{GmbH}$ (Frankfurt, Germany). R.A.B. has a non-commercial research agreement and is on the speakers list of Mediso Medical Imaging (Budapest, Hungary). M.E. is Consultant for Bayer Healthcare (Leverkusen, Germany) and Eisai GmbH (Frankfurt, Germany), IPSEN and Novartis. All other authors declare no conflict of interest and give their consent for scientific analysis and publication.

\section{References}

1. Lecocq, Q.; De Vlaeminck, Y.; Hanssens, H.; D’Huyvetter, M.; Raes, G.; Goyvaerts, C.; Keyaerts, M.; Devoogdt, N.; Breckpot, K. Theranostics in immuno-oncology using nanobody derivatives. Theranostics 2019, 9, 7772-7791. [CrossRef]

2. Wu, Y.; Jiang, S.; Ying, T. Single-domain antibodies as therapeutics against human viral diseases. Front. Immunol. 2017, 8, 1802. [CrossRef] [PubMed]

3. Xavier, C.; Blykers, A.; Vaneycken, I.; D’Huyvetter, M.; Heemskerk, J.; Lahoutte, T.; Devoogdt, N.; Caveliers, V. (18)F-nanobody for PET imaging of HER2 overexpressing tumors. Nucl. Med. Biol. 2016, 43, 247-252. [CrossRef] 
4. Rashidian, M.; Ploegh, H. Nanobodies as non-invasive imaging tools. Immuno-Oncol. Technol. 2020, 7, 2-14. [CrossRef]

5. Debie, P.; Lafont, C.; Defrise, M.; Hansen, I.; Van Willigen, D.M.; Van Leeuwen, F.W.B.; Gijsbers, R.; D'Huyvetter, M.; Devoogdt, N.; Lahoutte, T.; et al. Size and affinity kinetics of nanobodies influence targeting and penetration of solid tumours. J. Control. Release 2020, 317, 34-42. [CrossRef]

6. De Vos, J.; Devoogdt, N.; Lahoutte, T.; Muyldermans, S. Camelid single-domain antibody-fragment engineering for (pre)clinical in vivo molecular imaging applications: Adjusting the bullet to its target. Expert Opin. Biol. Ther. 2013, 13, 1149-1160. [CrossRef] [PubMed]

7. Debie, P.; Devoogdt, N.; Hernot, S. Targeted nanobody-based molecular tracers for nuclear imaging and image-guided surgery. Antibodies (Basel) 2019, 8, 12. [CrossRef]

8. Weber, J.; Haberkorn, U.; Mier, W. Cancer stratification by molecular imaging. Int. J. Mol. Sci. 2015, 16, 4918-4946. [CrossRef] [PubMed]

9. Shoghi, K.I. Quantitative small animal PET. Q. J. Nucl. Med. Mol. Imaging 2009, 53, 365-373.

10. Franc, B.L.; Seo, Y.; Flavell, R.; Aparici, C.M. Preclinical SPECT and SPECT-CT in Oncology. Recent Results Cancer Res. 2020, 216, 359-404. [CrossRef] [PubMed]

11. Schröder, H.; Erdi, Y.E.; Larson, S.M.; Yeung, H.W.D. PET/CT: A new imaging technology in nuclear medicine. Eur. J. Nucl. Med. Mol. Imaging 2003, 30, 1419-1437. [CrossRef] [PubMed]

12. Fu, R.; Carroll, L.; Yahioglu, G.; Aboagye, E.O.; Miller, P.W. Antibody fragment and affibody immunopet imaging agents: Radiolabelling strategies and applications. ChemMedChem 2018, 13, 2466-2478. [CrossRef]

13. Van Audenhove, I.; Gettemans, J. Nanobodies as versatile tools to understand, diagnose, visualize and treat cancer. EBioMedicine 2016, 8, 40-48. [CrossRef] [PubMed]

14. Jodal, A.; Pape, F.; Becker-Pauly, C.; Maas, O.; Schibli, R.; Béhé, M. Evaluation of ${ }^{111}$ In-labelled exendin-4 derivatives containing different meprin $\beta$-specific cleavable linkers. PLoS ONE 2015, 10, e123443. [CrossRef] [PubMed]

15. Zhou, Z.; Devoogdt, N.; Zalutsky, M.R.; Vaidyanathan, G. An efficient method for labeling single domain antibody fragments with ${ }^{18} \mathrm{f}$ using tetrazine- trans-cyclooctene ligation and a renal brush border enzyme-cleavable linker. Bioconjug. Chem. 2018, 29, 4090-4103. [CrossRef]

16. Massa, S.; Xavier, C.; De Vos, J.; Caveliers, V.; Lahoutte, T.; Muyldermans, S.; Devoogdt, N. Site-specific labeling of cysteine-tagged camelid single-domain antibody-fragments for use in molecular imaging. Bioconjug. Chem. 2014, 25, 979-988. [CrossRef]

17. Massa, S.; Xavier, C.; Muyldermans, S.; Devoogdt, N. Emerging site-specific bioconjugation strategies for radioimmunotracer development. Expert Opin. Drug Deliv. 2016, 13, 1149-1163. [CrossRef] [PubMed]

18. Massa, S.; Vikani, N.; Betti, C.; Ballet, S.; Vanderhaegen, S.; Steyaert, J.; Descamps, B.; Vanhove, C.; Bunschoten, A.; Van Leeuwen, F.W.B.; et al. Sortase A-mediated site-specific labeling of camelid single-domain antibody-fragments: A versatile strategy for multiple molecular imaging modalities. Contrast Media Mol. Imaging 2016, 11, 328-339. [CrossRef]

19. Cascini, G.L.; Niccoli Asabella, A.; Notaristefano, A.; Restuccia, A.; Ferrari, C.; Rubini, D.; Altini, C.; Rubini, G. ${ }^{124}$ Iodine: A longer-life positron emitter isotope-new opportunities in molecular imaging. Biomed. Res. Int. 2014, 2014, 672094. [CrossRef]

20. Josefsson, A.; Forssell-Aronsson, E. Dosimetric analysis of (123) I, (125) I and (131) I in thyroid follicle models. EJNMMI Res. 2014, 4, 23. [CrossRef]

21. Wang, P.; Ma, N.; Zhang, S.; Ning, X.; Guo, C.; Zhang, Q.; Cheng, Q.; Li, Y. Iodine-125 interstitial brachytherapy for malignant lacrimal sac tumours: An innovative technique. Eye Lond. 2020, 35, 1240-1247. [CrossRef] [PubMed]

22. Li, R.; Zhao, Y.; Chen, Y.; Liu, Z.; Han, B.; Li, Z.; Wang, J. Imidazolate ionic liquids for high-capacity capture and reliable storage of iodine. Commun. Chem. 2018, 1, s42004-s42018. [CrossRef]

23. Cavaliere, A.; Probst, K.C.; Paisey, S.J.; Marshall, C.; Dheere, A.K.H.; Aigbirhio, F.; McGuigan, C.; Westwell, A.D. Radiosynthesis of ${ }^{18}$ F-Labelled Pro-Nucleotides (ProTides). Molecules 2020, 25, 704. [CrossRef] [PubMed]

24. Clark, J.; O'Hagan, D. Strategies for radiolabelling antibody, antibody fragments and affibodies with fluorine-18 as tracers for positron emission tomography (PET). J. Fluor. Chem. 2017, 203, 31-46. [CrossRef]

25. Bailey, G.S. The iodogen method for radiolabeling protein. In The Protein Protocols Handbook; Walker, J.M., Ed.; Humana Press: Totowa, NJ, USA, 1996; pp. 673-674. ISBN 978-0-89603-338-2.

26. Pruszynski, M.; Koumarianou, E.; Vaidyanathan, G.; Revets, H.; Devoogdt, N.; Lahoutte, T.; Zalutsky, M.R. Targeting breast carcinoma with radioiodinated anti-HER2 Nanobody. Nucl. Med. Biol. 2013, 40, 52-59. [CrossRef]

27. Pruszynski, M.; Koumarianou, E.; Vaidyanathan, G.; Revets, H.; Devoogdt, N.; Lahoutte, T.; Lyerly, H.K.; Zalutsky, M.R. Improved tumor targeting of anti-HER2 nanobody through $\mathrm{N}$-succinimidyl 4-guanidinomethyl-3-iodobenzoate radiolabeling. J. Nucl. Med. 2014, 55, 650-656. [CrossRef] [PubMed]

28. Farah, K.; Farouk, N. Electrophilic radioiodination of tyrosine derivatives. J. Label. Compd. Radiopharm. 1998, 41, 255-259. [CrossRef]

29. Kothari, P.; De, B.P.; He, B.; Chen, A.; Chiuchiolo, M.J.; Kim, D.; Nikolopoulou, A.; Amor-Coarasa, A.; Dyke, J.P.; Voss, H.U.; et al. Radioiodinated capsids facilitate in vivo non-invasive tracking of adeno-associated gene transfer vectors. Sci. Rep. 2017, 7, 39594. [CrossRef]

30. Vaidyanathan, G.; McDougald, D.; Choi, J.; Pruszynski, M.; Koumarianou, E.; Zhou, Z.; Zalutsky, M.R. N-Succinimidyl 3-((4-(4(18) Ffluorobutyl)-1H-1,2,3-triazol-1-yl) methyl)-5-(guanidinomethyl) benzoate ((18) FSFBTMGMB): A residualizing label for (18) F-labeling of internalizing biomolecules. Org. Biomol. Chem. 2016, 14, 1261-1271. [CrossRef] 
31. Tran, L.; Baars, J.; Damen, C.; Beijnen, J.; Huitema, A. Three spectroscopic techniques evaluated as a tool to study the effects of iodination of monoclonal antibodies, exemplified by rituximab. J. Pharm. Biomed. Anal. 2011, 56, 609-614. [CrossRef]

32. Buell, A.K.; White, D.A.; Meier, C.; Welland, M.E.; Knowles, T.P.J.; Dobson, C.M. Surface attachment of protein fibrils via covalent modification strategies. J. Phys. Chem. B 2010, 114, 10925-10938. [CrossRef] [PubMed]

33. Choi, J.; Vaidyanathan, G.; Koumarianou, E.; McDougald, D.; Pruszynski, M.; Osada, T.; Lahoutte, T.; Lyerly, H.K.; Zalutsky, M.R. N-Succinimidyl guanidinomethyl iodobenzoate protein radiohalogenation agents: Influence of isomeric substitution on radiolabeling and target cell residualization. Nucl. Med. Biol. 2014, 41, 802-812. [CrossRef]

34. Zhou, Z.; Vaidyanathan, G.; McDougald, D.; Kang, C.M.; Balyasnikova, I.; Devoogdt, N.; Ta, A.N.; McNaughton, B.R.; Zalutsky, M.R. Fluorine-18 labeling of the HER2-targeting single-domain antibody 2Rs15d using a residualizing label and preclinical evaluation. Mol. Imaging Biol. 2017, 19, 867-877. [CrossRef] [PubMed]

35. Zhou, Z.; McDougald, D.; Meshaw, R.; Balyasnikova, I.; Zalutsky, M.R.; Vaidyanathan, G. Labeling single domain antibody fragments with ${ }^{18} \mathrm{~F}$ using a novel residualizing prosthetic agent-N-succinimidyl 3-(1-(2-(2-(2-(2-[ $\left.\left.{ }^{18} \mathrm{~F}\right] \mathrm{fluoroethoxy}\right)$ ethoxy)ethoxy)ethyl)1H-1,2,3-triazol-4-yl)-5-(guanidinomethyl)benzoate. Nucl. Med. Biol. 2021, 100-101, 24-35. [CrossRef] [PubMed]

36. Zhou, Z.; Chitneni, S.K.; Devoogdt, N.; Zalutsky, M.R.; Vaidyanathan, G. Fluorine-18 labeling of an anti-HER2 VHH using a residualizing prosthetic group via a strain-promoted click reaction: Chemistry and preliminary evaluation. Bioorg. Med. Chem. 2018, 26, 1939-1949. [CrossRef] [PubMed]

37. Zhou, Z.; McDougald, D.; Devoogdt, N.; Zalutsky, M.R.; Vaidyanathan, G. Labeling single domain antibody fragments with fluorine-18 Using 2,3,5,6-tetrafluorophenyl 6-[ $\left.{ }^{18} \mathrm{~F}\right]$ fluoronicotinate resulting in high tumor-to-kidney ratios. Mol. Pharm. 2019, 16, 214-226. [CrossRef] [PubMed]

38. Blykers, A.; Schoonooghe, S.; Xavier, C.; D’hoe, K.; Laoui, D.; D’Huyvetter, M.; Vaneycken, I.; Cleeren, F.; Bormans, G.; Heemskerk, J.; et al. pet imaging of macrophage mannose receptor-expressing macrophages in tumor stroma using ${ }^{18}$ f-radiolabeled camelid single-domain antibody fragments. J. Nucl. Med. 2015, 56, 1265-1271. [CrossRef]

39. Bala, G.; Blykers, A.; Xavier, C.; Descamps, B.; Broisat, A.; Ghezzi, C.; Fagret, D.; Van Camp, G.; Caveliers, V.; Vanhove, C.; et al. Targeting of vascular cell adhesion molecule- 1 by ${ }^{18} \mathrm{~F}$-labelled nanobodies for PET/CT imaging of inflamed atherosclerotic plaques. Eur. Heart J. Cardiovasc. Imaging 2016, 17, 1001-1008. [CrossRef]

40. Rashidian, M.; Keliher, E.; Dougan, M.; Juras, P.K.; Cavallari, M.; Wojtkiewicz, G.R.; Jacobsen, J.; Edens, J.G.; Tas, J.M.G.; Victora, G.; et al. The use of ${ }^{18} \mathrm{~F}$-2-fluorodeoxyglucose (FDG) to label antibody fragments for immuno-PET of pancreatic cancer. ACS Cent. Sci. 2015, 1, 142-147. [CrossRef]

41. Rashidian, M.; Keliher, E.J.; Bilate, A.M.; Duarte, J.N.; Wojtkiewicz, G.R.; Jacobsen, J.T.; Cragnolini, J.; Swee, L.K.; Victora, G.D.; Weissleder, R.; et al. Noninvasive imaging of immune responses. Proc. Natl. Acad. Sci. USA 2015, 112, 6146-6151. [CrossRef]

42. Rashidian, M.; Wang, L.; Edens, J.G.; Jacobsen, J.T.; Hossain, I.; Wang, Q.; Victora, G.D.; Vasdev, N.; Ploegh, H.; Liang, S.H. Enzyme-mediated modification of single-domain antibodies for imaging modalities with different characteristics. Angew. Chem. Int. Ed. Engl. 2016, 55, 528-533. [CrossRef]

43. Cheng, X.; Zhu, T.; Hong, H.; Zhou, Z.; Wu, Z. Sortase a-mediated on-resin peptide cleavage and in situ ligation: An efficient one-pot strategy for the synthesis of functional peptides and proteins. Org. Chem. Front. 2017, 4, 2058-2062. [CrossRef]

44. Guimaraes, C.P.; Witte, M.D.; Theile, C.S.; Bozkurt, G.; Kundrat, L.; Blom, A.E.M.; Ploegh, H.L. Site-specific C-terminal and internal loop labeling of proteins using sortase-mediated reactions. Nat. Protoc. 2013, 8, 1787-1799. [CrossRef] [PubMed]

45. Crauwels, M.; Massa, S.; Martin, C.; Betti, C.; Ballet, S.; Devoogdt, N.; Xavier, C.; Muyldermans, S. Site-Specific radioactive labeling of nanobodies. Methods Mol. Biol. 2018, 1827, 505-540. [CrossRef] [PubMed]

46. Ingram, J.R.; Dougan, M.; Rashidian, M.; Knoll, M.; Keliher, E.J.; Garrett, S.; Garforth, S.; Blomberg, O.S.; Espinosa, C.; Bhan, A.; et al. PD-L1 is an activation-independent marker of brown adipocytes. Nat. Commun. 2017, 8, 1-10. [CrossRef] [PubMed]

47. Ingram, J.R.; Blomberg, O.S.; Rashidian, M.; Ali, L.; Garforth, S.; Fedorov, E.; Fedorov, A.A.; Bonanno, J.B.; Le Gall, C.; Crowley, S.; et al. Anti-CTLA-4 therapy requires an Fc domain for efficacy. Proc. Natl. Acad. Sci. USA 2018, 115, $3912-3917$. [CrossRef]

48. McBride, W.J.; D’Souza, C.A.; Karacay, H.; Sharkey, R.M.; Goldenberg, D.M. New lyophilized kit for rapid radiofluorination of peptides. Bioconjug. Chem. 2012, 23, 538-547. [CrossRef]

49. Cleeren, F.; Lecina, J.; Ahamed, M.; Raes, G.; Devoogdt, N.; Caveliers, V.; McQuade, P.; Rubins, D.J.; Li, W.; Verbruggen, A.; et al. $\mathrm{Al}^{18} \mathrm{~F}$-labeling of heat-sensitive biomolecules for positron emission tomography imaging. Theranostics 2017, 7, $2924-2939$. [CrossRef]

50. Cleeren, F.; Lecina, J.; Bridoux, J.; Devoogdt, N.; Tshibangu, T.; Xavier, C.; Bormans, G. Direct fluorine-18 labeling of heat-sensitive biomolecules for positron emission tomography imaging using the Al ${ }^{18}$ F-RESCA method. Nat. Protoc. 2018, 13, 2330-2347. [CrossRef]

51. Bridoux, J.; Neyt, S.; Debie, P.; Descamps, B.; Devoogdt, N.; Cleeren, F.; Bormans, G.; Broisat, A.; Caveliers, V.; Xavier, C.; et al. Improved detection of molecular markers of atherosclerotic plaques using sub-millimeter PET imaging. Molecules 2020, $25,1838$. [CrossRef]

52. Zhou, Z.; Zalutsky, M.R.; Vaidyanathan, G. Labeling a TCO-functionalized single domain antibody fragment with ${ }^{18} \mathrm{~F}$ via inverse electron demand Diels Alder cycloaddition using a fluoronicotinyl moiety-bearing tetrazine derivative. Bioorg. Med. Chem. 2020, 28, 115634. [CrossRef] [PubMed] 
53. Bala, G.; Baudhuin, H.; Remory, I.; Gillis, K.; Debie, P.; Krasniqi, A.; Lahoutte, T.; Raes, G.; Devoogdt, N.; Cosyns, B.; et al. Evaluation of $\left[{ }^{99 \mathrm{~m}} \mathrm{Tc}\right.$ ] radiolabeled macrophage mannose receptor-specific nanobodies for targeting of atherosclerotic lesions in mice. Mol. Imaging Biol. 2018, 20, 260-267. [CrossRef] [PubMed]

54. Xavier, C.; Vaneycken, I.; D’Huyvetter, M.; Heemskerk, J.; Keyaerts, M.; Vincke, C.; Devoogdt, N.; Muyldermans, S.; Lahoutte, T.; Caveliers, V. Synthesis, preclinical validation, dosimetry, and toxicity of ${ }^{68} \mathrm{Ga}-\mathrm{NOTA}-\mathrm{anti}-\mathrm{HER} 2$ Nanobodies for iPET imaging of HER2 receptor expression in cancer. J. Nucl. Med. 2013, 54, 776-784. [CrossRef] [PubMed]

55. Jiang, L.; Tu, Y.; Hu, X.; Bao, A.; Chen, H.; Ma, X.; Doyle, T.; Shi, H.; Cheng, Z. Pilot study of ${ }^{64} \mathrm{Cu}(\mathrm{I})$ for PET imaging of melanoma. Sci. Rep. 2017, 7, 1-10. [CrossRef] [PubMed]

56. Fassbender, M.E. Guest edited collection: Radioisotopes and radiochemistry in health science. Sci. Rep. 2020, 10, 340. [CrossRef]

57. Varani, M.; Auletta, S.; Signore, A.; Galli, F. State of the art of natural killer cell imaging: A systematic review. Cancers (Basel) 2019, 11, 967. [CrossRef] [PubMed]

58. Dash, A.; Pillai, M.R.A.; Knapp, F.F. Production of (177) Lu for targeted radionuclide therapy: Available options. Nucl. Med. Mol. Imaging 2015, 49, 85-107. [CrossRef]

59. Lemaire, M.; D'Huyvetter, M.; Lahoutte, T.; Van Valckenborgh, E.; Menu, E.; De Bruyne, E.; Kronenberger, P.; Wernery, U.; Muyldermans, S.; Devoogdt, N.; et al. Imaging and radioimmunotherapy of multiple myeloma with anti-idiotypic Nanobodies. Leukemia 2014, 28, 444-447. [CrossRef]

60. Sadkin, V.; Skuridin, V.; Nesterov, E.; Stasyuk, E.; Rogov, A.; Varlamova, N.; Zelchan, R. 99m Tc-labeled nanocolloid drugs: Development methods. Sci. Rep. 2020, 10,1-9. [CrossRef]

61. Xavier, C.; Devoogdt, N.; Hernot, S.; Vaneycken, I.; D’Huyvetter, M.; De Vos, J.; Massa, S.; Lahoutte, T.; Caveliers, V. Site-specific labeling of his-tagged Nanobodies with ${ }^{99 \mathrm{~m}} \mathrm{Tc}$ : A practical guide. Methods Mol. Biol. 2012, 911, 485-490. [CrossRef]

62. Van Elssen, C.H.M.J.; Rashidian, M.; Vrbanac, V.; Wucherpfennig, K.W.; Habre, Z.E.; Sticht, J.; Freund, C.; Jacobsen, J.T.; Cragnolini, J.; Ingram, J.; et al. Noninvasive imaging of human immune responses in a human xenograft model of graft-versus-host disease. J. Nucl. Med. 2017, 58, 1003-1008. [CrossRef]

63. Jailkhani, N.; Ingram, J.R.; Rashidian, M.; Rickelt, S.; Tian, C.; Mak, H.; Jiang, Z.; Ploegh, H.L.; Hynes, R.O. Noninvasive imaging of tumor progression, metastasis, and fibrosis using a nanobody targeting the extracellular matrix. Proc. Natl. Acad. Sci. USA 2019, 116, 14181-14190. [CrossRef] [PubMed]

64. Senders, M.L.; Hernot, S.; Carlucci, G.; Van de Voort, J.C.; Fay, F.; Calcagno, C.; Tang, J.; Alaarg, A.; Zhao, Y.; Ishino, S.; et al. Nanobody-facilitated multiparametric PET/MRI phenotyping of atherosclerosis. JACC Cardiovasc. Imaging 2019, 12, $2015-2026$. [CrossRef]

65. Varasteh, Z.; Mohanta, S.; Li, Y.; López Armbruster, N.; Braeuer, M.; Nekolla, S.G.; Habenicht, A.; Sager, H.B.; Raes, G.; Weber, W.; et al. Targeting mannose receptor expression on macrophages in atherosclerotic plaques of apolipoprotein E-knockout mice using ${ }^{68} \mathrm{Ga}-\mathrm{NOTA}$-anti-MMR nanobody: Non-invasive imaging of atherosclerotic plaques. EJNMMI Res. 2019, 9, 1-10. [CrossRef]

66. Bala, G.; Crauwels, M.; Blykers, A.; Remory, I.; Marschall, A.L.J.; Dübel, S.; Dumas, L.; Broisat, A.; Martin, C.; Ballet, S.; et al. Radiometal-labeled anti-VCAM-1 nanobodies as molecular tracers for atherosclerosis-impact of radiochemistry on pharmacokinetics. Biol. Chem. 2019, 400, 323-332. [CrossRef]

67. Zhao, H.; Wang, C.; Yang, Y.; Sun, Y.; Wei, W.; Wang, C.; Wan, L.; Zhu, C.; Li, L.; Huang, G.; et al. ImmunoPET imaging of human CD8+ T cells with novel ${ }^{68} \mathrm{Ga}$-labeled nanobody companion diagnostic agents. J. Nanobiotechnol. 2021, 19, 1-11. [CrossRef] [PubMed]

68. Wang, C.; Chen, Y.; Hou, Y.N.; Liu, Q.; Zhang, D.; Zhao, H.; Zhang, Y.; An, S.; Li, L.; Hou, J.; et al. ImmunoPET imaging of multiple myeloma with $\left[{ }^{68} \mathrm{Ga}\right] \mathrm{Ga}-\mathrm{NOTA}-\mathrm{Nb} 1053$. Eur. J. Nucl. Med. Mol. Imaging 2021. [CrossRef] [PubMed]

69. Bridoux, J.; Broos, K.; Lecocq, Q.; Debie, P.; Martin, C.; Ballet, S.; Raes, G.; Neyt, S.; Vanhove, C.; Breckpot, K.; et al. Anti-human PD-L1 nanobody for immuno-PET imaging: Validation of a conjugation strategy for clinical translation. Biomolecules 2020, 10, 1388. [CrossRef] [PubMed]

70. Lv, G.; Sun, X.; Qiu, L.; Sun, Y.; Li, K.; Liu, Q.; Zhao, Q.; Qin, S.; Lin, J. PET imaging of tumor PD-11 expression with a highly specific nonblocking single-domain antibody. J. Nucl. Med. 2020, 61, 117-122. [CrossRef]

71. Krasniqi, A.; D’Huyvetter, M.; Xavier, C.; Van der Jeught, K.; Muyldermans, S.; Van der Heyden, J.; Lahoutte, T.; Tavernier, J.; Devoogdt, N. theranostic radiolabeled anti-CD20 sdAb for targeted radionuclide therapy of non-hodgkin lymphoma. Mol. Cancer Ther. 2017, 16, 2828-2839. [CrossRef]

72. Demine, S.; Garcia Ribeiro, R.; Thevenet, J.; Marselli, L.; Marchetti, P.; Pattou, F.; Kerr-Conte, J.; Devoogdt, N.; Eizirik, D.L. A nanobody-based nuclear imaging tracer targeting dipeptidyl peptidase 6 to determine the mass of human beta cell grafts in mice. Diabetologia 2020, 63, 825-836. [CrossRef]

73. Chigoho, D.M.; Lecocq, Q.; Awad, R.M.; Breckpot, K.; Devoogdt, N.; Keyaerts, M.; Caveliers, V.; Xavier, C.; Bridoux, J. Site-specific Radiolabeling of a human PD-L1 nanobody via maleimide-cysteine chemistry. Pharmaceuticals (Basel) 2021, 14, 550. [CrossRef]

74. Vosjan, M.J.W.D.; Perk, L.R.; Roovers, R.C.; Visser, G.W.M.; Stigter-van Walsum, M.; van Bergen En Henegouwen, P.M.P.; van Dongen, G.A.M.S. Facile labelling of an anti-epidermal growth factor receptor Nanobody with ${ }^{68} \mathrm{Ga}$ via a novel bifunctional desferal chelate for immuno-PET. Eur. J. Nucl. Med. Mol. Imaging 2011, 38, 753-763. [CrossRef] [PubMed] 
75. Leung, K. ${ }^{89}$ Zr-Desferrioxamine $p$-Isothiocyanatobenzyl-Anti-EGFR Nanobody 7D12. In Molecular Imaging and Contrast Agent Database (MICAD). Bethesda (MD), National Center for Biotechnology Information (US). 2004. Available online: http: / / www.ncbi.nlm.nih.gov/books/NBK97356/ (accessed on 18 May 2021).

76. Vosjan, M.J.W.D.; Vercammen, J.; Kolkman, J.A.; Stigter-van Walsum, M.; Revets, H.; van Dongen, G.A.M.S. Nanobodies targeting the hepatocyte growth factor: Potential new drugs for molecular cancer therapy. Mol. Cancer Ther. 2012, 11, 1017-1025. [CrossRef] [PubMed]

77. Lesniak, W.G.; Chu, C.; Jablonska, A.; Behnam Azad, B.; Zwaenepoel, O.; Zawadzki, M.; Lisok, A.; Pomper, M.G.; Walczak, P.; Gettemans, J.; et al. PET imaging of distinct brain uptake of a nanobody and similarly-sized PAMAM dendrimers after intra-arterial administration. Eur. J. Nucl. Med. Mol. Imaging 2019, 46, 1940-1951. [CrossRef] [PubMed]

78. Warnders, F.J.; van Terwisscha Scheltinga, A.G.T.; Knuehl, C.; van Roy, M.; de Vries, E.F.J.; Kosterink, J.G.W.; de Vries, E.G.E.; Lub-de Hooge, M.N. Human epidermal growth factor receptor 3-specific tumor uptake and biodistribution of ${ }^{89} \mathrm{Zr}-\mathrm{MSB} 0010853$ visualized by real-time and noninvasive PET Imaging. J. Nucl. Med. 2017, 58, 1210-1215. [CrossRef]

79. Rashidian, M.; Ingram, J.R.; Dougan, M.; Dongre, A.; Whang, K.A.; LeGall, C.; Cragnolini, J.J.; Bierie, B.; Gostissa, M.; Gorman, J.; et al. Predicting the response to CTLA-4 blockade by longitudinal noninvasive monitoring of CD8 T cells. J. Exp. Med. 2017, 214, 2243-2255. [CrossRef]

80. Rashidian, M.; LaFleur, M.W.; Verschoor, V.L.; Dongre, A.; Zhang, Y.; Nguyen, T.H.; Kolifrath, S.; Aref, A.R.; Lau, C.J.; Paweletz, C.P.; et al. Immuno-PET identifies the myeloid compartment as a key contributor to the outcome of the antitumor response under PD-1 blockade. Proc. Natl. Acad. Sci. USA 2019, 116, 16971-16980. [CrossRef] [PubMed]

81. Price, E.W.; Orvig, C. Matching chelators to radiometals for radiopharmaceuticals. Chem. Soc. Rev. 2014, 43, 260-290. [CrossRef] [PubMed]

82. Chatalic, K.L.S.; Veldhoven-Zweistra, J.; Bolkestein, M.; Hoeben, S.; Koning, G.A.; Boerman, O.C.; De Jong, M.; Van Weerden, W.M. A Novel ${ }^{111}$ in-labeled anti-prostate-specific membrane antigen nanobody for targeted SPECT/CT imaging of prostate cancer. J. Nucl. Med. 2015, 56, 1094-1099. [CrossRef]

83. Rotman, M.; Welling, M.M.; Bunschoten, A.; De Backer, M.E.; Rip, J.; Nabuurs, R.J.A.; Gaillard, P.J.; Van Buchem, M.A.; Van der Maarel, S.M.; Van der Weerd, L. Enhanced glutathione PEGylated liposomal brain delivery of an anti-amyloid single domain antibody fragment in a mouse model for Alzheimer's disease. J. Control. Release 2015, 203, 40-50. [CrossRef] [PubMed]

84. Balhuizen, A.; Massa, S.; Mathijs, I.; Turatsinze, J.V.; De Vos, J.; Demine, S.; Xavier, C.; Villate, O.; Millard, I.; Egrise, D.; et al. A nanobody-based tracer targeting DPP6 for non-invasive imaging of human pancreatic endocrine cells. Sci. Rep. 2017, 7, 1-13. [CrossRef] [PubMed]

85. D'Huyvetter, M.; Vincke, C.; Xavier, C.; Aerts, A.; Impens, N.; Baatout, S.; De Raeve, H.; Muyldermans, S.; Caveliers, V.; Devoogdt, N.; et al. Targeted radionuclide therapy with a ${ }^{177}$ Lu-labeled anti-HER2 nanobody. Theranostics $2014,4,708-720$. [CrossRef]

86. Krasniqi, A.; Bialkowska, M.; Xavier, C.; Van der Jeught, K.; Muyldermans, S.; Devoogdt, N.; D’Huyvetter, M. Pharmacokinetics of radiolabeled dimeric sdAbs constructs targeting human CD20. New Biotechnol. 2018, 45, 69-79. [CrossRef] [PubMed]

87. D'Huyvetter, M.; Aerts, A.; Xavier, C.; Vaneycken, I.; Devoogdt, N.; Gijs, M.; Impens, N.; Baatout, S.; Ponsard, B.; Muyldermans, S.; et al. Development of ${ }^{177} \mathrm{Lu}$-nanobodies for radioimmunotherapy of HER2-positive breast cancer: Evaluation of different bifunctional chelators. Contrast Media Mol. Imaging 2012, 7, 254-264. [CrossRef]

88. Romão, E.; Krasniqi, A.; Maes, L.; Vandenbrande, C.; Sterckx, Y.G.J.; Stijlemans, B.; Vincke, C.; Devoogdt, N.; Muyldermans, S. Identification of nanobodies against the acute myeloid leukemia marker CD33. Int. J. Mol. Sci. 2020, 21, 310. [CrossRef]

89. Gainkam, L.O.T.; Huang, L.; Caveliers, V.; Keyaerts, M.; Hernot, S.; Vaneycken, I.; Vanhove, C.; Revets, H.; De Baetselier, P.; Lahoutte, T. Comparison of the biodistribution and tumor targeting of two ${ }^{99 \mathrm{~m}}$ Tc-labeled anti-EGFR nanobodies in mice, using pinhole SPECT/micro-CT. J. Nucl. Med. 2008, 49, 788-795. [CrossRef]

90. Movahedi, K.; Schoonooghe, S.; Laoui, D.; Houbracken, I.; Waelput, W.; Breckpot, K.; Bouwens, L.; Lahoutte, T.; de Baetselier, P.; Raes, G.; et al. Nanobody-based targeting of the macrophage mannose receptor for effective in vivo imaging of tumor-associated macrophages. Cancer Res. 2012, 72, 4165-4177. [CrossRef] [PubMed]

91. Put, S.; Schoonooghe, S.; Devoogdt, N.; Schurgers, E.; Avau, A.; Mitera, T.; D’Huyvetter, M.; de Baetselier, P.; Raes, G.; Lahoutte, T.; et al. SPECT imaging of joint inflammation with Nanobodies targeting the macrophage mannose receptor in a mouse model for rheumatoid arthritis. J. Nucl. Med. 2013, 54, 807-814. [CrossRef]

92. Broisat, A.; Hernot, S.; Toczek, J.; De Vos, J.; Riou, L.M.; Martin, S.; Ahmadi, M.; Thielens, N.; Wernery, U.; Caveliers, V.; et al. Nanobodies targeting mouse/human VCAM1 for the nuclear imaging of atherosclerotic lesions. Circ. Res. 2012, 110, 927-937. [CrossRef]

93. Broisat, A.; Toczek, J.; Dumas, L.S.; Ahmadi, M.; Bacot, S.; Perret, P.; Slimani, L.; Barone-Rochette, G.; Soubies, A.; Devoogdt, N.; et al. ${ }^{99 \mathrm{~m}} \mathrm{Tc}-\mathrm{cAbVCAM} 1-5$ imaging is a sensitive and reproducible tool for the detection of inflamed atherosclerotic lesions in mice. J. Nucl. Med. 2014, 55, 1678-1684. [CrossRef]

94. Broos, K.; Keyaerts, M.; Lecocq, Q.; Renmans, D.; Nguyen, T.; Escors, D.; Liston, A.; Raes, G.; Breckpot, K.; Devoogdt, N. Noninvasive assessment of murine PD-L1 levels in syngeneic tumor models by nuclear imaging with nanobody tracers. Oncotarget 2017, 8, 41932-41946. [CrossRef] 
95. Xing, Y.; Chand, G.; Liu, C.; Cook, G.J.R.; O’Doherty, J.; Zhao, L.; Wong, N.C.L.; Meszaros, L.K.; Ting, H.H.; Zhao, J. Early phase i study of a ${ }^{99} \mathrm{~m}$ Tc-labeled anti-programmed death ligand-1 (PD-L1) single-domain antibody in SPECT/CT assessment of PD-L1 expression in non-small cell lung cancer. J. Nucl. Med. 2019, 60, 1213-1220. [CrossRef] [PubMed]

96. Zheng, F.; Put, S.; Bouwens, L.; Lahoutte, T.; Matthys, P.; Muyldermans, S.; de Baetselier, P.; Devoogdt, N.; Raes, G.; Schoonooghe, S. Molecular imaging with macrophage CRIg-targeting nanobodies for early and preclinical diagnosis in a mouse model of rheumatoid arthritis. J. Nucl. Med. 2014, 55, 824-829. [CrossRef] [PubMed]

97. De Vos, J.; Mathijs, I.; Xavier, C.; Massa, S.; Wernery, U.; Bouwens, L.; Lahoutte, T.; Muyldermans, S.; Devoogdt, N. Specific targeting of atherosclerotic plaques in ApoE(-/-) mice using a new Camelid sdAb binding the vulnerable plaque marker LOX-1. Mol. Imaging Biol. 2014, 16, 690-698. [CrossRef] [PubMed]

98. Verhelle, A.; Van Overbeke, W.; Peleman, C.; Smet, R.D.; Zwaenepoel, O.; Lahoutte, T.; Van Dorpe, J.; Devoogdt, N.; Gettemans, J. Non-invasive imaging of amyloid deposits in a mouse model of agel using ${ }^{99 \mathrm{~m}} \mathrm{Tc}-$ modified nanobodies and SPECT/CT. Mol. Imaging Biol. 2016, 18, 887-897. [CrossRef] [PubMed]

99. Verhelle, A.; Nair, N.; Everaert, I.; Van Overbeke, W.; Supply, L.; Zwaenepoel, O.; Peleman, C.; Van Dorpe, J.; Lahoutte, T.; Devoogdt, N.; et al. AAV9 delivered bispecific nanobody attenuates amyloid burden in the gelsolin amyloidosis mouse model. Hum. Mol. Genet. 2017, 26, 1353-1364. [CrossRef]

100. Evazalipour, M.; D’Huyvetter, M.; Tehrani, B.S.; Abolhassani, M.; Omidfar, K.; Abdoli, S.; Arezumand, R.; Morovvati, H.; Lahoutte, T.; Muyldermans, S.; et al. Generation and characterization of nanobodies targeting PSMA for molecular imaging of prostate cancer. Contrast Media Mol. Imaging 2014, 9, 211-220. [CrossRef] [PubMed]

101. Nabuurs, R.J.A.; Rutgers, K.S.; Welling, M.M.; Metaxas, A.; De Backer, M.E.; Rotman, M.; Bacskai, B.J.; Van Buchem, M.A.; Van der Maarel, S.M.; Van der Weerd, L. In vivo detection of amyloid- $\beta$ deposits using heavy chain antibody fragments in a transgenic mouse model for Alzheimer's disease. PLoS ONE 2012, 7, e38284. [CrossRef]

102. Vaneycken, I.; Govaert, J.; Vincke, C.; Caveliers, V.; Lahoutte, T.; De Baetselier, P.; Raes, G.; Bossuyt, A.; Muyldermans, S.; Devoogdt, $\mathrm{N}$. In vitro analysis and in vivo tumor targeting of a humanized, grafted nanobody in mice using pinhole SPECT/micro-CT. $J$. Nucl. Med. 2010, 51, 1099-1106. [CrossRef]

103. Montemagno, C.; Bacot, S.; Ahmadi, M.; Kerfelec, B.; Baty, D.; Debiossat, M.; Soubies, A.; Perret, P.; Riou, L.; Fagret, D.; et al. Preclinical evaluation of mesothelin-specific ligands for SPECT imaging of triple-negative breast cancer. J. Nucl. Med. 2018, 59, 1056-1062. [CrossRef]

104. De Groeve, K.; Deschacht, N.; de Koninck, C.; Caveliers, V.; Lahoutte, T.; Devoogdt, N.; Muyldermans, S.; de Baetselier, P.; Raes, G. Nanobodies as tools for in vivo imaging of specific immune cell types. J. Nucl. Med. 2010, 51, 782-789. [CrossRef] [PubMed]

105. Zheng, F.; Sparkes, A.; De Baetselier, P.; Schoonooghe, S.; Stijlemans, B.; Muyldermans, S.; Flamand, V.; Van Ginderachter, J.A.; Devoogdt, N.; Raes, G.; et al. molecular imaging with Kupffer cell-targeting nanobodies for diagnosis and prognosis in mouse models of liver pathogenesis. Mol. Imaging Biol. 2017, 19, 49-58. [CrossRef] [PubMed]

106. Lecocq, Q.; Awad, R.M.; De Vlaeminck, Y.; De Mey, W.; Ertveldt, T.; Goyvaerts, C.; Raes, G.; Thielemans, K.; Keyaerts, M.; Devoogdt, N.; et al. Nanobody nuclear imaging allows noninvasive quantification of LAG-3 expression by tumor-infiltrating leukocytes and predicts response of immune checkpoint blockade. J. Nucl. Med. 2021. [CrossRef] [PubMed]

107. Lecocq, Q.; Zeven, K.; De Vlaeminck, Y.; Martens, S.; Massa, S.; Goyvaerts, C.; Raes, G.; Keyaerts, M.; Breckpot, K.; Devoogdt, N. Noninvasive imaging of the immune checkpoint LAG-3 using nanobodies, from development to pre-clinical use. Biomolecules 2019, 9, 548. [CrossRef] [PubMed]

108. Randolph, T.W. The two faces of His-tag: Immune response versus ease of protein purification. Biotechnol. J. 2012, 7, 18-19. [CrossRef]

109. Khan, F.; Legler, P.M.; Mease, R.M.; Duncan, E.H.; Bergmann-Leitner, E.S.; Angov, E. Histidine affinity tags affect MSP1(42) structural stability and immunodominance in mice. Biotechnol. J. 2012, 7, 133-147. [CrossRef] [PubMed]

110. Waibel, R.; Alberto, R.; Willuda, J.; Finnern, R.; Schibli, R.; Stichelberger, A.; Egli, A.; Abram, U.; Mach, J.P.; Plückthun, A.; et al. Stable one-step technetium-99m labeling of His-tagged recombinant proteins with a novel Tc(I)-carbonyl complex. Nat. Biotechnol. 1999, 17, 897-901. [CrossRef] [PubMed]

111. Gao, H.; Wu, Y.; Shi, J.; Zhang, X.; Liu, T.; Hu, B.; Jia, B.; Wan, Y.; Liu, Z.; Wang, F. Nuclear imaging-guided PD-L1 blockade therapy increases effectiveness of cancer immunotherapy. J. Immunother. Cancer 2020, 8, e001156. [CrossRef]

112. Ye, Y.; Toczek, J.; Gona, K.; Kim, H.Y.; Han, J.; Razavian, M.; Golestani, R.; Zhang, J.; Wu, T.L.; Ghosh, M.; et al. Novel arginine-containing macrocyclic MMP inhibitors: Synthesis, ${ }^{99 \mathrm{~m}} \mathrm{Tc}-$ labeling, and evaluation. Sci. Rep. 2018, 8, 1-14. [CrossRef]

113. Duclos, V.; Iep, A.; Gomez, L.; Goldfarb, L.; Besson, F.L. PET molecular imaging: A holistic review of current practice and emerging perspectives for diagnosis, therapeutic evaluation and prognosis in clinical oncology. Int. J. Mol. Sci. 2021, 22, 4159. [CrossRef] [PubMed]

114. Rowe, S.P.; Johnson, G.B.; Pomper, M.G.; Gorin, M.A.; Behr, S.C. Recent updates and developments in PET imaging of prostate cancer. Abdom. Radiol. N. Y. 2020, 45, 4063-4072. [CrossRef] [PubMed]

115. Shi, S.; Goel, S.; Lan, X.; Cai, W. ImmunoPET of CD38 with a radiolabeled nanobody: Promising for clinical translation. Eur. J. Nucl. Med. Mol. Imaging 2021, 48, 2683-2686. [CrossRef] [PubMed]

116. Gebhart, G.; Lamberts, L.E.; Wimana, Z.; Garcia, C.; Emonts, P.; Ameye, L.; Stroobants, S.; Huizing, M.; Aftimos, P.; Tol, J.; et al. Molecular imaging as a tool to investigate heterogeneity of advanced HER2-positive breast cancer and to predict patient outcome under trastuzumab emtansine (T-DM1): The ZEPHIR trial. Ann. Oncol. 2016, 27, 619-624. [CrossRef] [PubMed] 
117. Dittrich, D.; Pyka, T.; Scheidhauer, K.; Lütje, S.; Essler, M.; Bundschuh, R.A. Textural features in FDG-PET/CT can predict outcome in melanoma patients to treatment with Vemurafenib and Ipililumab. Nuklearmedizin 2020, 59, 228-234. [CrossRef]

118. Hartmann, L.; Bundschuh, L.; Zsótér, N.; Essler, M.; Bundschuh, R.A. Tumorheterogenität zur differenzierung zwischen lebertumoren und gesundem lebergewebe in ${ }^{18}$ F-FDG-PET/CT. Nuklearmedizin 2021, 60, 25-32. [CrossRef]

119. Eary, J.F.; Brenner, W. Brauchen wir quantitative Bildgebung? Nuklearmedizin 2020, 59, 225-226. [CrossRef] [PubMed]

120. Pektor, S.; Lawaczeck, L.; Tenzer, S.; Bausbacher, N.; Hoffmann, M.A.; Schreckenberger, M.; Miederer, M. Charakterisierung der aktivierungsinduzierten ${ }^{18}$ F-FDG-Aufnahme in dendritische Zellen. Nuklearmedizin 2021, 60, 90-98. [CrossRef]

121. Nahrendorf, M.; McCarthy, J.R.; Libby, P. Over a hump for imaging atherosclerosis: Nanobodies visualize vascular cell adhesion molecule-1 in inflamed plaque. Circ. Res. 2012, 110, 902-903. [CrossRef] 